\title{
CAN YOU HEAR ME NOW? A COMPARATIVE SURVEY OF PINNIPED AUDITORY APPARATUS MORPHOLOGY
}

\author{
L. Koper ${ }^{1 \star}$, I. A. Koretsky², S. J. Rahmat ${ }^{3}$ \\ Laboratory of Evolutionary Biology, Department of Anatomy, College of Medicine, \\ Howard University 520 W St. NW, Washington, DC 20059 (USA) \\ ${ }^{1 *}$ Corresponding author

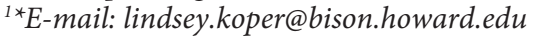 \\ ${ }^{2}$ E-mail: ikoretsky@howard.com \\ ${ }^{3}$ E-mail: sulman.rahmat@howard.edu \\ L. Koper (https://orcid.org/0000-0002-1773-9843) \\ S. J. Rahmat (https://orcid.org/0000-0001-7410-8178)
}

Can You Hear Me Now? A Comparative Survey of Pinniped Auditory Apparatus Morphology. Koper, L., Koretsky, I. A., Rahmat, S. J. - Over the past century research on the morphology of the auditory apparatuses of pinnipeds, which include Phocidae (true seals), Otariidae (sea lions and fur seals), and Odobenidae (walruses) is extremely limited, in comparison to other Carnivora. Although, the auditory region and surrounding basicrania are areas that are evolutionarily conservative, most literature is unclear due to mixed terminology, inaccurate information, and indistinct, outdated illustrations. The lack of adequate and current studies demonstrates the need for compiling morphological information of the auditory region of modern carnivores in relation to hearing. Auditory terminology will be explored to show morphological comparisons and naming practices among the carnivoran families. By streamlining accurate terminology with straightforward illustrations, the behavioral information gleaned from auditory morphological structures will be clearer even among the diverse members of Carnivora. This initial assessment will detail the limited information in prior research on the hearing adaptations for transitional semiaquatic carnivores. This preliminary review will help to establish the adaptive patterns (from land to sea) in the basicranial morphology of early pinnipeds, especially in phocids.

Key words: Carnivores, Pinnipedia, Auditory bulla.

\section{Introduction}

The early mammalian ear is one of the better-preserved fossil transitions that evolved millions of years ago and allowed for early vertebrates to have better hearing on land (Kardong, 2009; Ekdale, 2015). One of the drastic changes that can be seen between the auditory apparatus of reptiles and amphibians and the apparatus of mammals is the number of auditory ossicles. Reptiles and amphibians only have one ossicle (fig. 1, C) that is homologous to the mammalian stapes. Mammals added two more ossicles, the malleus and incus, creating a longer, more efficient ossicular chain (fig. 1, C-D). These two other bones used to be called the angular (malleus) and quadrate (incus) and were part of the reptilian jaw articulation. As mammals evolved and more of their skull bones began to fuse, the smaller postdentary bones that were part of the jaw grew even smaller. They became encased within the cranium joining the mammalian hearing apparatus (Kardong, 2009). 
A

B

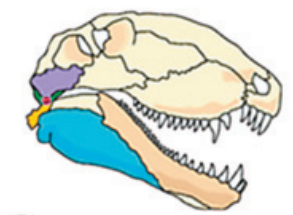

C

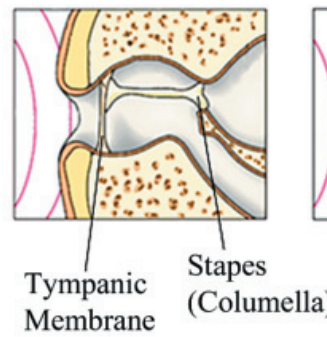

D
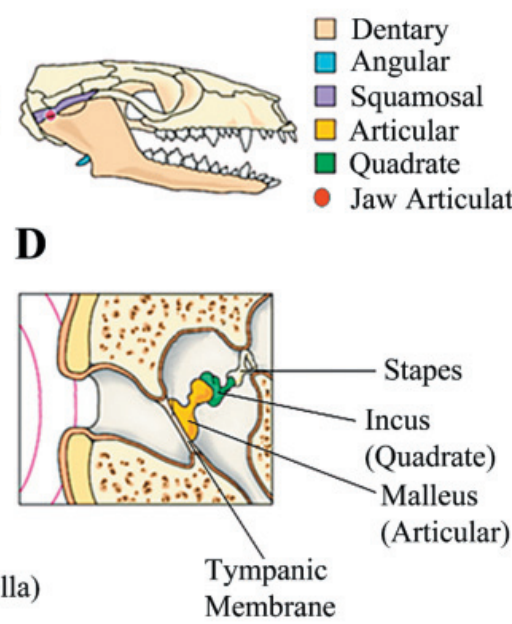

Fig. 1. Comparisons of Reptilian and Mammalian Ears: A Pelycosaur; B - Early mammal; C - Reptilian middle ear; D Mammalian middle ear (modified from Pearson Education Inc).

A

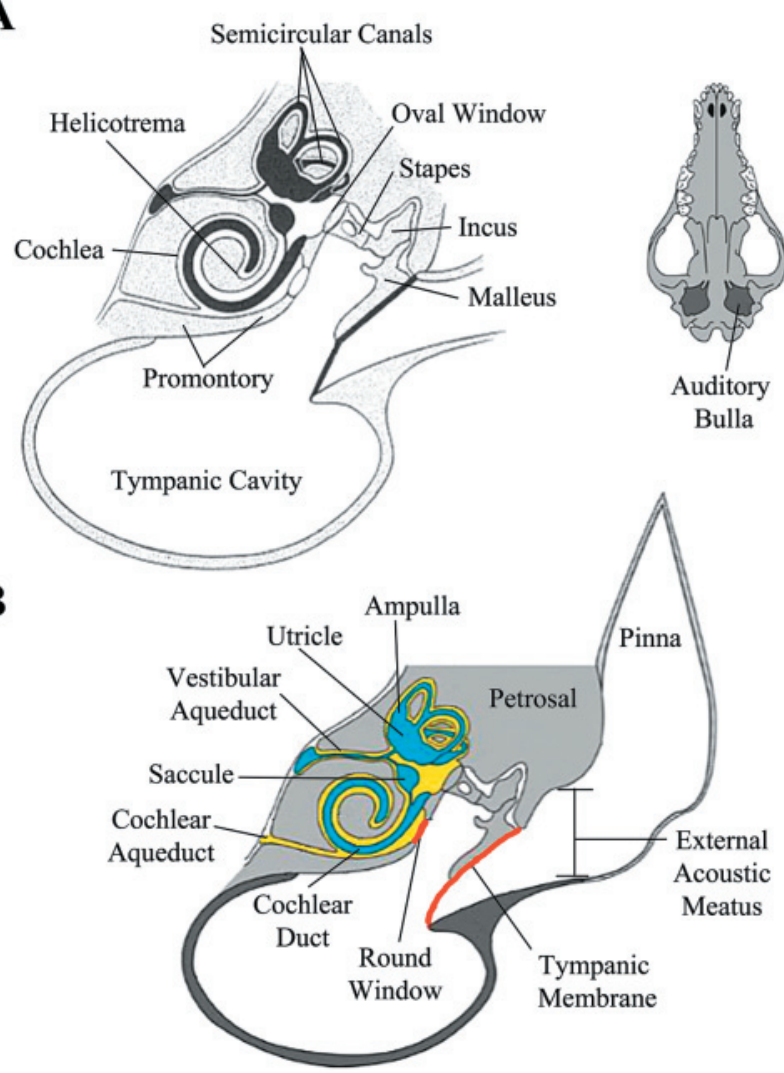

Fig. 2. Generalized Mammalian Ear: A - Cross-section through a domestic dog (Canis familiaris) showing all three parts of the ear (modified from Ekdale, 2015); B - Inside auditory bulla of a general carnivore. Blue indicates structures of the membranous labyrinth, yellow indicates structures of the bony labyrinth, and red indicates both the tympanic membrane and the (secondary tympanic) membrane spanning the round window (modified from Wang and Tedford, 2008).
As mammals continued to develop more derived traits for terrestrial life, a specific group of predators emerged approximately 42 million years ago. These mammals possessed specialized meat slicing dentition and are known as the Carnivora (Polly et al., 2006). All possess carnassial dentition at some point in their evolutionary history (Kardong, 2009). Modern carnivoran ears consist of similar components, and function comparable to a typical mammalian ear due to evolving in a terrestrial environment (figs 2-3).

A typical mammalian ear transmits airborne sound waves through the rhythmic movement of an ossicular chain to a specialized portion of the ear where they are translated into electrical signals for the brain (Davis et al., 1934; Kardong, 2009). These components are divided into three adjoining compartments: external, middle, and inner ear. The structures found in these compartments can vary morphologically based on environmental conditions as well as phylogenetic relationships (Kardong, 2009; Ekdale, 2013, 2015; Bastl et al., 2017).

\section{Terminology}

Part of this review intends to identify the most accurate anatomical terms for auditory structures of carnivores by using the most current and inclusive literary sources. Some of these sources include the Nomina Anatomica Veterinaria (2017) which will be referred to as NAV in the rest of this paper, the Illustrated Veterinary Anatomical Nomenclature (2018) which will be referred to as IVAN henceforth, and multiple editions of Miller's Anatomy of the Dog (Evans and Christiansen, 1979; Evans, 1993; Hermanson et al., 2020). Below, is a preliminary table of auditory terminology of the basicrania and middle ear (table 1). It can be used to streamline discussions of carnivoran auditory anatomy regardless of a human-based anatomy or comparative anatomy background. This is achieved by including definitions and if applicable, the previous terms applied to the same structure. The bolded terms in the first column are the terms used in this paper and terms in the second column with $\left(^{*}\right)$ are additional equivalent terms for carnivores and more specifically, pinnipeds.

Following the framework of NAV (2017), the table is organized initially by the Latin terminology of the cranial 
bones and under those terms, the individual structures are alphabetized by their Latin names. This table is still preliminary and does not include all auditory terminology. Throughout the rest of this paper auditory terminology not referenced in the table will include both Latin and English names.

\section{General Mammalian Ear}

The generic mammalian ear takes in sound waves through the external orifice of the external acoustic meatus (table 1) which is usually surrounded by a cartilaginous external pinna (fig.

2). Even though external pinnae can be used for temperature regulation, the primary function of this structure is to differentiate airborne sounds from multiple directions and funnel them to the external acoustic meatus found beyond the external orifice (Kardong, 2009). The presence of bilateral ears allows for the auditory fields to overlap, giving the organism stereophonic hearing. Animals that can orient the cartilaginous flaps of their pinnae in different directions have greater directional acuity, as seen in domestic dogs and cats. Not all mammals have external pinnae, instead possessing other adaptations that aid in directional hearing (to be discussed later). Once airborne sound reaches the end of the external acoustic meatus, it stimulates the tympanic membrane. Vibrations of this membrane then activate the connected ossicular chain made up of three small bones: the malleus, incus, and stapes (fig. $2, \mathrm{~A})$. The stapes is at the innermost end of this chain and vibrates against an open structure known as the oval window.

On the medial side of the oval window is the inner ear compartment, where the cochlea for hearing and the semicircular canals for balance are located. The oval window itself is connected to an area known as the vestibule that contains both perilymphatic and endolymphatic fluid. These fluids carry sound waves in the inner ear and help transfer airborne sound into electrical signals. Generally, the fluid found here is incompressible, so a second opening located on the vestibule, called the round window, aids in dealing with displacing fluid (fig. 2, B). The stapes transfers energy to the fluid at the oval window, and after passing through the entirety of the cochlea, ends at the round window. Because the round window is covered with a secondary tympanic membrane, lymphatic fluid can 'bulge out' displacing any remaining energy (Repenning, 1972). The movement of the fluid in the cochlea and stimulation of hair cells in appropriate areas is how the brain processes sound.

Displaced fluid from the cochlea travels toward the semicircular canals to process balance and orientation. In this inner ear region, there are receptors sensitive to linear head movements, called the saccule (which detects along the vertical axis) and the utricle (which detects along the longitudinal axis; fig. 2, B). The semicircular canals are sensitive to rotational head movements or also known as pitch (anterior-posterior movements), roll (left-right movements on a vertical plane) and yaw (left-right movements on a horizontal plane; fig. 3; Kardong, 2009; Ekdale, 2015). At the ends of each of the three semicircular canals are enlarged structures known as ampullae. In each of these regions is a cupula that registers spatial orientation.

\section{Pinnipeds and the Aquatic Specializations for Hearing}

Pinnipeds are a group of specialized semi-aquatic mammals within the Order Carnivora (Koretsky et al., 2016; Deméré et al., 2003; Berta et al., 2018). Compared to other terrestrial carnivores, all extant members of Phocidae (true seals), Otariidae (fur seals and 
Table 1. Basicrania and Associated Auditory Terminology

\begin{tabular}{|c|c|c|}
\hline Terms Used in this Paper & $\begin{array}{l}\text { Previously Used } \\
\text { Synonyms }\end{array}$ & Definition \\
\hline $\begin{array}{l}\text { Os occipitale (Occipital Bone) } \\
\text { (NAV, 2017; IVAN, 2018; } \\
\text { Hermanson et al., 2020) }\end{array}$ & & $\begin{array}{l}\text { Most posterior bone of the skull and forms } \\
\text { around the spinal cord as it exits the skull } \\
\text { (Hermanson et al., 2020). }\end{array}$ \\
\hline $\begin{array}{l}\text { Canalis } \boldsymbol{n} \text {. hypoglossi (Hypoglossal } \\
\text { canal) } \\
\text { (Gray, 1913; NAV, 2017; IVAN, 2018) }\end{array}$ & $\begin{array}{l}\text { Foramen hypoglossis } \\
\text { (Loza et al., 2015) }\end{array}$ & $\begin{array}{l}\text { Canal for cranial nerve XII located near the } \\
\text { foramen magnum (IVAN, 2018). }\end{array}$ \\
\hline $\begin{array}{l}\text { Foramen magnum } \\
\text { (Gray, 1913; Loza et al., 2015; } \\
\text { NAV, 2017; IVAN, 2018) }\end{array}$ & & $\begin{array}{l}\text { Large opening in the occipital bone for the } \\
\text { medulla oblongata and spinal cord (IVAN, 2018; } \\
\text { Hermanson et al., 2020). }\end{array}$ \\
\hline $\begin{array}{l}\text { Processus jugularis (jugular process) } \\
\text { (NAV, 2017; IVAN, 2018) }\end{array}$ & $\begin{array}{l}\text { Jugluar apophysis } \\
\text { (Loza et al., 2015) } \\
\text { Anterior crista } \\
\text { (Loza et al., 2015) }\end{array}$ & $\begin{array}{l}\text { Process lateral to the foramen jugulare, } \\
\text { corresponding to a transverse process of a } \\
\text { vertebra. Not the same as paracondylar process } \\
\text { (NAV, 2017; IVAN, 2018). }\end{array}$ \\
\hline $\begin{array}{l}\text { Processus paracondylaris } \\
\text { (Paracondylar process) } \\
\text { (NAV, 2017; IVAN, 2018; } \\
\text { Hermanson et al., 2020) }\end{array}$ & $\begin{array}{l}\text { Processus paraoccipitalis } \\
\text { (Paroccipital process) } \\
\text { (Loza et al., 2015) } \\
\text { Processus jugularis (Jugular } \\
\text { process)(Evans, 1993) }\end{array}$ & $\begin{array}{l}\text { This structure projects from the occipital condyle } \\
\text { and is an apophysis for muscular attachment in } \\
\text { Carnivores. The jugular process is found at the } \\
\text { base of this structure in Carnivores and is not } \\
\text { considered the same thing (IVAN, 2018). }\end{array}$ \\
\hline $\begin{array}{l}\text { Pars basilaris (Basioccipital) } \\
\text { (NAV, 2017; IVAN, 2018; } \\
\text { Hermanson et al., 2020) }\end{array}$ & & $\begin{array}{l}\text { Ventral or basilar portion of the occipital } \\
\text { bone that is unpaired. In some literature is } \\
\text { referred to as a separate bone from the occipital } \\
\text { (Hermanson et al., 2020). }\end{array}$ \\
\hline $\begin{array}{l}\text { Foramen jugulare (Jugular } \\
\text { foramen) } \\
\text { (Gray, 1913; Loza et al., 2015; NAV, } \\
2017 \text {; IVAN, 2018) }\end{array}$ & $\begin{array}{l}\text { Tympano-occipital fissure* } \\
\text { (Hermanson et al., 2020) } \\
\text { Posterior lacerate foramen } \\
\text { (Hough, 1948; Tedford, } \\
\text { 1976; Wolsan, 1993; } \\
\text { Loza et al., 2015) }\end{array}$ & $\begin{array}{l}\text { An opening located between the occipital and } \\
\text { petrosal for passage of cranial nerves IX, X, and } \\
\text { XI as well as the sigmoid sinus (becoming the } \\
\text { jugular vein). This opening can be referred to as the } \\
\text { tympano-occipital fissure (identified in Canis) when } \\
\text { the internal carotid a. enters here as well because the } \\
\text { jugular foramen can be found internal to the fissure } \\
\text { (Hunt, 1974; IVAN, 2017; Hermanson et al., 2020). }\end{array}$ \\
\hline $\begin{array}{l}\text { Os temporale (Temporal Bone) } \\
\text { (Romer and Parsons, 1986; NAV, } \\
\text { 2017; IVAN, 2018; Hermanson et al., } \\
2020)\end{array}$ & $\begin{array}{l}\text { Squamosal bone } \\
\text { (Romer and Parsons, 1986) }\end{array}$ & $\begin{array}{l}\text { The overall name for this bone is temporal. Some } \\
\text { references will refer to it as the squamosal but } \\
\text { that is incorrect when referencing the entire } \\
\text { bone. In mammals, it is the squamosal along } \\
\text { with other bones that fuse to form what is known } \\
\text { as the temporal bone (Romer and Parsons, 1986; } \\
\text { Kardong, 2009). }\end{array}$ \\
\hline $\begin{array}{l}\text { Pars petrosa (Petrosal, Petrosum) } \\
\text { (NAV, 2017; IVAN, 2018; } \\
\text { Hermanson et al., 2020) }\end{array}$ & $\begin{array}{l}\text { Pyramid } \\
\text { (Hermanson et al., 2020) }\end{array}$ & $\begin{array}{l}\text { Petrous portion of the temporal bone and } \\
\text { surrounds the osseous labyrinth of the inner ear. } \\
\text { Pyramid is not as accurate because in humans } \\
\text { it refers specifically to the attachment area of } \\
\text { the stapedius m. (Gray, 1913; IVAN, 2018; } \\
\text { Hermanson et al., 2020). }\end{array}$ \\
\hline $\begin{array}{l}\text { Auris media (Middle ear) } \\
\text { (NAV, 2017; IVAN; 2018; } \\
\text { Hermanson et al., 2020) }\end{array}$ & & $\begin{array}{l}\text { The area of the middle ear, which consists of the } \\
\text { tympanic cavity, tympanic membrane, auditory } \\
\text { ossicles, and the auditory tube (IVAN, 2018). }\end{array}$ \\
\hline $\begin{array}{l}\text { Canalis facialis (Facial canal) } \\
\text { (NAV, 2017; IVAN; 2018; } \\
\text { Hermanson et al., 2020) }\end{array}$ & & $\begin{array}{l}\text { Canal for facial nerve, originates in the } \\
\text { internal acoustic meatus and terminates at the } \\
\text { stylomastoid foramen (IVAN, 2018). }\end{array}$ \\
\hline $\begin{array}{l}\text { Cavum tympani (Tympanic cavity) } \\
\text { (NAV, 2017; IVAN, 2018; } \\
\text { Hermanson et al., 2020) }\end{array}$ & & $\begin{array}{l}\text { The oblique space between the petrosal and } \\
\text { tympanic portion of the temporal. Within } \\
\text { this space, the auditory ossicles transmit the } \\
\text { vibrations of the tympanic membrane to the fluid } \\
\text { of the inner ear (IVAN, 2018). }\end{array}$ \\
\hline $\begin{array}{l}\text { Crista partis petrosae } \\
\text { (NAV, 2017; IVAN; 2018; } \\
\text { Hermanson et al., 2020) }\end{array}$ & & $\begin{array}{l}\text { Sharp crest in Canis between rostral and medial } \\
\text { surfaces of the petrosal (IVAN, 2018). }\end{array}$ \\
\hline $\begin{array}{l}\text { Crista transversa (Transverse crest) } \\
\text { (NAV, 2017; IVAN; 2018; } \\
\text { Hermanson et al., 2020) }\end{array}$ & & $\begin{array}{l}\text { A crest dividing the fundus of the internal } \\
\text { acoustic meatus into upper and lower parts } \\
\text { (IVAN, 2018; Hermanson et al., 2020). }\end{array}$ \\
\hline $\begin{array}{l}\text { Ectotympanic (tympanic) notch } \\
\text { (Wible and Spaulding, 2012) }\end{array}$ & & $\begin{array}{l}\text { A pit in the ectotympanic where the rostral } \\
\text { portion of the rostral process fits into (Wible and } \\
\text { Spaulding, 2012). }\end{array}$ \\
\hline
\end{tabular}


Continued Table 1:

\begin{tabular}{|c|c|c|}
\hline Terms Used in this Paper & $\begin{array}{l}\text { Previously Used } \\
\text { Synonyms }\end{array}$ & Definition \\
\hline $\begin{array}{l}\text { External cochlear foramen } \\
\text { (Repenning, 1972; Amson and de } \\
\text { Muizon, 2014) }\end{array}$ & $\begin{array}{l}\text { Foramen 'A' (Loza et al., 2015) } \\
\text { Annexae mastoidae, cavum } \\
\text { tympani (Thomassin et al., } \\
\text { 2008; Loza et al., 2015) }\end{array}$ & $\begin{array}{l}\text { In phocids, allows the secondary tympanic } \\
\text { membrane, that covers the round window, to } \\
\text { expand out external to the skull (Repenning, } \\
\text { 1972). }\end{array}$ \\
\hline $\begin{array}{l}\text { Fenestra cochleae } \\
\text { (Cochlear window, Round Window) } \\
\text { (Gray, 1913, Wang and Tedford, } \\
\text { 2008; Paul 2014; Ekdale 2015; NAV, } \\
\text { 2017; IVAN, 2018; Hermanson et } \\
\text { al., 2020) }\end{array}$ & $\begin{array}{l}\text { Fenestra rotunda* } \\
\text { (Paul, 2014) }\end{array}$ & $\begin{array}{l}\text { Round foramen in the medial wall of the } \\
\text { tympanic cavity, communicating to the Scala } \\
\text { tympani, closed by the Membrana tympani } \\
\text { secundaria (IVAN, 2018). }\end{array}$ \\
\hline $\begin{array}{l}\text { Fenestra vestibuli } \\
\text { (Vestibular window, Oval Window) } \\
\text { (Gray, 1913, Wang and Tedford, } \\
\text { 2008; Ekdale 2015; NAV, 2017; } \\
\text { IVAN, 2018; Hermanson et al., 2020) }\end{array}$ & $\begin{array}{l}\text { Fenestra ovalis* } \\
\text { (Paul, 2014) }\end{array}$ & $\begin{array}{l}\text { Opening closed by the base of the stapes by } \\
\text { means of which the vibrations act on the } \\
\text { perilymph in the internal ear (IVAN, 2018). }\end{array}$ \\
\hline $\begin{array}{l}\text { Foramen stylomastoideum } \\
\text { (Stylomastoid foramen) } \\
\text { (Gray, 1913, Loza et al., 2015; } \\
\text { NAV, 2017; IVAN, 2018) }\end{array}$ & & $\begin{array}{l}\text { Opening of the canalis facialis or facial canal } \\
\text { (IVAN, 2018). }\end{array}$ \\
\hline $\begin{array}{l}\text { Fossa cerebellaris (Cerebellar fossa) } \\
\text { (NAV, 2017; Hermanson et al., 2020) }\end{array}$ & $\begin{array}{l}\text { Fossa subarcuata (subarcuate } \\
\text { fossa) (IVAN; 2018) }\end{array}$ & $\begin{array}{l}\text { Deep depression dorsal to the opening of the } \\
\text { interanl acoustic meatus in carnivores and contains } \\
\text { the paraflocculus of the cerebellum. In some } \\
\text { anatomical literature this opening is referred to } \\
\text { as the subarcuate fossa which is only supposed to } \\
\text { contain the flocculus at a young age and transitions } \\
\text { to only containing a vein later in life. Due to } \\
\text { the differences in cerebellar surface anatomy in } \\
\text { carnivores, a more incompassing name should } \\
\text { be the cerebellar fossa (NAV, 2017; IVAN, 2018; } \\
\text { Hermanson et al., 2020; Mennink et al., 2020). }\end{array}$ \\
\hline $\begin{array}{l}\text { Fundus meatus acustici interni } \\
\text { (Fundus of the internal acoustic } \\
\text { meatus) (NAV, 2017; IVAN; 2018; } \\
\text { Hermanson et al., 2020) }\end{array}$ & & $\begin{array}{l}\text { The floor of the internal acoustic meatus (IVAN, } \\
\text { 2018). }\end{array}$ \\
\hline $\begin{array}{l}\text { Meatus acusticus internus } \\
\text { (Internal acoustic meatus) } \\
\text { (NAV, 2017; IVAN; 2018; } \\
\text { Hermanson et al., 2020) }\end{array}$ & $\begin{array}{l}\text { Internal auditory canal } \\
\text { (IVAN, 2018) }\end{array}$ & $\begin{array}{l}\text { Passage in the medial surface of the petrosal bone } \\
\text { for the facial and vestibulocochlear cranial nerves. } \\
\text { It is more appropriate to refer to this structure as } \\
\text { 'acoustic' and not 'auditory' to be consistent with the } \\
\text { translation (IVAN, 2018; Hermanson et al., 2020). }\end{array}$ \\
\hline $\begin{array}{l}\text { Membrana tympani secundaria } \\
\text { (Secondary tympanic membrane) } \\
\text { (NAV, 2017; IVAN, 2018) }\end{array}$ & & $\begin{array}{l}\text { The membrane that covers the round window and } \\
\text { prevents the fluid of the inner ear from spilling out } \\
\text { while vibrational waves are passing through the } \\
\text { cochlea (IVAN, 2018; Hermanson et al., 2020). }\end{array}$ \\
\hline $\begin{array}{l}\text { Ossicula auditus (Auditory ossicles) } \\
\text { (NAV, 2017; IVAN, 2018; } \\
\text { Hermanson et al., 2020) } \\
\end{array}$ & & $\begin{array}{l}\text { The three auditory ossicles that transmit the } \\
\text { vibrations of the tympanic membrane across the } \\
\text { tympanic cavity (IVAN, 2018). }\end{array}$ \\
\hline $\begin{array}{l}\text { Porus acusticus internus (Opening } \\
\text { of the internal acoustic meatus) } \\
\text { (NAV, 2017; IVAN; 2018; } \\
\text { Hermanson et al., 2020) }\end{array}$ & $\begin{array}{l}\text { Internal acoustic meatus } \\
\text { (Wyss, 1987) }\end{array}$ & $\begin{array}{l}\text { The orifice or opening to the internal acoustic } \\
\text { meatus should be differentiated from the actual } \\
\text { meatus (IVAN, 2018; Hermanson et al., 2020). }\end{array}$ \\
\hline $\begin{array}{l}\text { Processus mastoideus } \\
\text { (Mastoid process) } \\
\text { (Gray, 1913; Loza et al., 2015; } \\
\text { NAV, 2017; IVAN, 2018) } \\
\end{array}$ & & $\begin{array}{l}\text { Ventral process, caudal to the external acoustic } \\
\text { meatus, part of the petrosal portion of the } \\
\text { temporal bone (Kardong, 2009; IVAN, 2018). }\end{array}$ \\
\hline $\begin{array}{l}\text { Promontorium (promontory) } \\
\text { (NAV, 2017; IVAN, 2018; } \\
\text { Hermanson et al., 2020) }\end{array}$ & & $\begin{array}{l}\text { The convexity on the medial wall of the tympanic } \\
\text { cavity caused by the most basal turn of the } \\
\text { cochlea (IVAN, 2018). }\end{array}$ \\
\hline $\begin{array}{l}\text { Recessus epitympanicus } \\
\text { (Epitympanic recess) (NAV, 2017; } \\
\text { IVAN, 2018; Hermanson et al., 2020) } \\
\end{array}$ & & $\begin{array}{l}\text { Dorsal part of the tympanic cavity, containing } \\
\text { the auditory ossicles (IVAN, 2018). }\end{array}$ \\
\hline $\begin{array}{l}\text { Sulcus malleolaris } \\
\text { (Wible and Spaulding, 2012) }\end{array}$ & & $\begin{array}{l}\text { The space lies beyond the ectotympanic notch } \\
\text { and the tympanic plate of the malleus passes } \\
\text { through here (Wible and Spaulding, 2012). }\end{array}$ \\
\hline
\end{tabular}


Continued Table 1:

\begin{tabular}{|c|c|c|}
\hline Terms Used in this Paper & $\begin{array}{l}\text { Previously Used } \\
\text { Synonyms }\end{array}$ & Definition \\
\hline $\begin{array}{l}\text { Tegmen tympani } \\
\text { (NAV, 2017; IVAN, 2018) }\end{array}$ & & $\begin{array}{l}\text { The roof of the tympanic cavity or middle ear } \\
\text { cavity (IVAN, 2018). }\end{array}$ \\
\hline $\begin{array}{l}\text { Pars squamosa } \\
\text { (Squamous part of Temporal) } \\
\text { (NAV, 2017; IVAN, 2018; } \\
\text { Hermanson et al., 2020) }\end{array}$ & $\begin{array}{l}\text { Squamosal bone } \\
\text { (Romer and Parsons, 1986) }\end{array}$ & $\begin{array}{l}\text { The flattened, dorsal portion of the temporal } \\
\text { bone that connects to the parietal bone (NAV, } \\
\text { 2017; IVAN, 2018; Hermanson et al., 2020). }\end{array}$ \\
\hline $\begin{array}{l}\text { Foramen retroarticularis } \\
\text { (Retroarticular foramen) } \\
\text { (NAV, 2017; IVAN, 2018) }\end{array}$ & $\begin{array}{l}\text { Foramen postglenoideum } \\
\text { (postglenoid foramen) } \\
\text { (Loza et al., 2015) }\end{array}$ & $\begin{array}{l}\text { External opening of the meatus temporalis (sinus } \\
\text { temporalis), rudimentary in Felis (IVAN, 2018). }\end{array}$ \\
\hline $\begin{array}{l}\text { Fossa mandibularis } \\
\text { (Mandibular fossa) } \\
\text { (Gray 1913; NAV, 2017; IVAN, 2018) }\end{array}$ & $\begin{array}{l}\text { Glenoid fossa }^{*} \\
\text { (Wible and Spaulding, 2012; } \\
\text { Loza et al., 2015) } \\
\text { Eustachian apophysis, } \\
\text { ectotympanic/endotympanic } \\
\text { suture (Loza et al., 2015) }\end{array}$ & $\begin{array}{l}\text { Fossa for the condyle of the manible (IVAN, } \\
\text { 2018). }\end{array}$ \\
\hline $\begin{array}{l}\text { Processus retroarticularis } \\
\text { (Retroarticular process) } \\
\text { (Loza et al., 2015; NAV, 2017; IVAN, } \\
\text { 2018; Hermanson et al., 2020) }\end{array}$ & $\begin{array}{l}\text { Postglenoid process } \\
\text { (Segall, 1943; Wible and } \\
\text { Spaulding, 2012; } \\
\text { Loza et al., 2015) } \\
\text { Postglenoid tubercle } \\
\text { (Agur and Dalley, 2009) } \\
\end{array}$ & $\begin{array}{l}\text { The process caudal to the glenoid fossa that helps to } \\
\text { keep the condyle of the mandible in the temporal- } \\
\text { mandibular joint (IVAN, 2018; Hermanson et al., } \\
\text { 2020). }\end{array}$ \\
\hline $\begin{array}{l}\text { Pars tympanica } \\
\text { (Tympanic part of the Temporal) } \\
\text { (NAV, 2017; IVAN, 2018; } \\
\text { Hermanson et al., 2020) }\end{array}$ & $\begin{array}{l}\text { Tympanicum* } \\
\text { (Hermanson et al., 2020) }\end{array}$ & $\begin{array}{l}\text { Ventral part of the temporal bone that includes } \\
\text { the auditory bulla (NAV, 2017; IVAN, 2018; } \\
\text { Hermanson et al., 2020). }\end{array}$ \\
\hline $\begin{array}{l}\text { Anterior crus of ectotympanic } \\
\text { (Wible 2008; 2011) }\end{array}$ & $\begin{array}{l}\text { Anterior leg of Tympanic } \\
\text { (Henson, 1961) } \\
\text { Crus Anterior } \\
\text { (NAV, 2005) } \\
\text { Anulus Tympanicus } \\
\text { (NAV, 2005) }\end{array}$ & $\begin{array}{l}\text { For Carnivores, this term is used to describe the rostral } \\
\text { portion of the ectotympanic before fusion occurs with } \\
\text { the other bullar elements; only seen in juveniles when } \\
\text { there is still a lot of cartilage present. Once fusions } \\
\text { occurs, it is the Anulus tympanicus (Hunt, 1974; Wible } \\
\text { and Spaulding, 2012; Hermanson et al., 2020). }\end{array}$ \\
\hline $\begin{array}{l}\text { Anterior foramen of canalis } \\
\text { caroticus (Anterior foramen of } \\
\text { carotid canal) } \\
\text { (Loza et al., 2015) }\end{array}$ & $\begin{array}{l}\text { Foramen lacerum, external } \\
\text { carotid foramen } \\
\text { (Loza et al., 2015; } \\
\text { Hermanson et al., 2020) } \\
\text { Rostral carotid foramen* } \\
\text { (Hermanson et al., 2020) } \\
\text { Middle lacerate foramen } \\
\text { (Romer and Parsons, 1986; } \\
\text { MacPhee, 1981; Wible, 1991) }\end{array}$ & $\begin{array}{l}\text { This term is used when the internal carotid a. visibly } \\
\text { exits the medial portion of the auditory bulla in the } \\
\text { rostral direction. It should be noted that veterinary } \\
\text { sources do not use 'foramen lacerum' for Carnivores } \\
\text { (Loza et al., 2015; NAV, 2017; IVAN, 2018). }\end{array}$ \\
\hline $\begin{array}{l}\text { Anulus tympanicus } \\
\text { (tympanic annulus) } \\
\text { (Wible and Spaulding, 2012; } \\
\text { NAV, 2017; IVAN, 2018) } \\
\end{array}$ & $\begin{array}{l}\text { Tympanic ring* } \\
\text { (Novacek, 1977; } \\
\text { Hermanson et al., 2020) }\end{array}$ & $\begin{array}{l}\text { Thin ring of bone which almost completely } \\
\text { surrounds the tympanic membrane and this term } \\
\text { is used when all bony fusion is complete (Hunt, } \\
\text { 1974; IVAN, 2018) }\end{array}$ \\
\hline $\begin{array}{l}\text { Bulla tympanica (Tympanic bulla) } \\
\text { (Loza et al., 2015; NAV, 2017; } \\
\text { IVAN, 2018; Hermanson et al., 2020) }\end{array}$ & $\begin{array}{l}\text { Auditory bulla* } \\
\text { (Hunt, 1974; Wible and } \\
\text { Spaulding, 2012) }\end{array}$ & $\begin{array}{l}\text { The bulbous enlargement of both the tympanic } \\
\text { part of the temporal bone and the entotympanic } \\
\text { bone which forms the floor of the middle ear } \\
\text { cavity (Evans and Christensen, 1979). }\end{array}$ \\
\hline $\begin{array}{l}\text { Canalis caroticus (Carotid canal) } \\
\text { (NAV, 2017; IVAN, 2018; } \\
\text { Hermanson et al., 2020) }\end{array}$ & & $\begin{array}{l}\text { A canal through the medial wall of the auditory } \\
\text { bulla for the internal carotid artery (A. carotis } \\
\text { interna) seen in carnivores (IVAN, 2018; } \\
\text { Hermanson et al., 2020). }\end{array}$ \\
\hline $\begin{array}{l}\text { Canalis musculotubarius } \\
\text { (musculotubal canal) } \\
\text { (NAV, 2017; IVAN, 2018; } \\
\text { Hermanson et al., 2020) } \\
\end{array}$ & $\begin{array}{l}\text { External foramen of the } \\
\text { auditory tube (Pocock 1916) } \\
\text { Anterior opening of auditory } \\
\text { tube (Ivanoff, 2001) }\end{array}$ & $\begin{array}{l}\text { Double canal leading into the tympanic cavity } \\
\text { for the } t u b a \text { auditiva and the tensor veli palatini, } \\
\text { formed by the basisphenoid in Carnivores } \\
\text { (IVAN, 2018). }\end{array}$ \\
\hline $\begin{array}{l}\text { Ectotympanic bone } \\
\text { (Van der Klaauw, 1922; Henson, } \\
\text { 1961; Loza et al., 2015; } \\
\text { Wible and Spaulding, 2012) }\end{array}$ & $\begin{array}{l}\text { Pars Tympanica } \\
\text { (NAV, 2017; IVAN, 2018; } \\
\text { Hermanson et al., 2020) } \\
\text { Os Temporale (NAV, 2017; } \\
\text { IVAN, 2018) } \\
\text { Tympanic or tympanic part } \\
\text { of temporal bone (Flower, } \\
\text { 1869; Hunt, 1974) }\end{array}$ & $\begin{array}{l}\text { The dermal element the makes up the tympanic } \\
\text { ring in mammals and part of the auditory bulla; } \\
\text { thought to be homologous to the angular in } \\
\text { reptiles (Novacek, 1977). }\end{array}$ \\
\hline
\end{tabular}


Continued Table 1:

\begin{tabular}{|c|c|c|}
\hline Terms Used in this Paper & $\begin{array}{l}\text { Previously Used } \\
\text { Synonyms }\end{array}$ & Definition \\
\hline $\begin{array}{l}\text { Ectotympanic tubercle } \\
\text { (Loza et al., 2015) }\end{array}$ & $\begin{array}{l}\text { Ossified meatal trough of } \\
\text { ectotympanic } \\
\text { (Wolsan, 1993) } \\
\text { Fossa condylaris ventralis } \\
\text { (Loza et al., 2015) }\end{array}$ & $\begin{array}{l}\text { Found in phocids where the lateral portion of } \\
\text { the osseous external acoustic meatus creates a } \\
\text { distinct 'point'. This observation was to identify } \\
\text { the sexual dimorphism seen in these marine } \\
\text { mammals (Loza et al., 2015). }\end{array}$ \\
\hline $\begin{array}{l}\text { Meatus acusticus externus } \\
\text { (External acoustic meatus) } \\
\text { (Gray, 1913; Loza et al., 2015; NAV, } \\
\text { 2017; IVAN, 2018; Hermanson et } \\
\text { al., 2020) }\end{array}$ & $\begin{array}{l}\text { External auditory meatus } \\
\text { (canal) } \\
\text { (Langman and } \\
\text { Woerddeman, 1978; } \\
\text { Morton, 1989) } \\
\text { Postglenoid apophysis, } \\
\text { tympanic process } \\
\text { (Loza et al., 2015) } \\
\end{array}$ & $\begin{array}{l}\text { The (both osseus and soft tissue) canal leading } \\
\text { from the base of the auricle to the tympanic } \\
\text { membrane. It is noted only the medical } \\
\text { professionals for humans use the term external } \\
\text { auditory meatus which is not the official term to } \\
\text { use (IVAN, 2018). }\end{array}$ \\
\hline $\begin{array}{l}\text { Porus acusticus externus } \\
\text { (Opening of the external acoustic } \\
\text { meatus) } \\
\text { (NAV, 2017; IVAN, 2018) }\end{array}$ & & $\begin{array}{l}\text { Opening of the ossoeus part of the external acoustic } \\
\text { meatus, visible from the lateral view of the skull. } \\
\text { This should be differentiated from the meatus itself } \\
\text { (IVAN, 2018, Hermanson et al., 2020). }\end{array}$ \\
\hline $\begin{array}{l}\text { Posterior crus of ectotympanic } \\
\text { (Wible, 2008; 2011) }\end{array}$ & $\begin{array}{l}\text { Posterior leg of Tympanic* } \\
\text { (Henson, 1961) } \\
\text { Crus Posterior } \\
\text { (NAV, 2005) }\end{array}$ & $\begin{array}{l}\text { This term refers to the caudal portion of the } \\
\text { ectotympanic before fusion occurs with the } \\
\text { other bullar elements; only seen in juveniles. } \\
\text { Once fusion occurs, is referred to as the Anulus } \\
\text { tympanicus (Hunt, 1974; Wible and Spaulding, } \\
\text { 2012; Hermanson et al., 2020). }\end{array}$ \\
\hline $\begin{array}{l}\text { Posterior foramen of canalis } \\
\text { caroticus (posterior foramen of } \\
\text { carotid canal) } \\
\text { (Loza et al., 2015) }\end{array}$ & $\begin{array}{l}\text { Foramen caroticum caudalis } \\
\text { (Caudal carotid foramen) } \\
\text { (Hermanson et al., 2020) } \\
\text { Carotid foramen } \\
\text { (Amson and de Muizon, 2014) } \\
\text { Combined with 'foramen } \\
\text { jugulare' (Wible, 1991; 2010) } \\
\text { Posterior carotid foramen } \\
\text { (Wolsan, 1993) }\end{array}$ & $\begin{array}{l}\text { This term is used when the internal carotid a. enters } \\
\text { the medial wall of the auditory bulla separately } \\
\text { from the jugular foramen. Not all Carnivores have } \\
\text { a separate opening for this artery (Hunt, 1974, Loza } \\
\text { et al., 2015). }\end{array}$ \\
\hline $\begin{array}{l}\text { Rostral entotympanic bone } \\
\text { (Hunt, 1974; Van der Klaauw, 1922) }\end{array}$ & & $\begin{array}{l}\text { Generally, most carnivores exhibit one } \\
\text { entotympanic bone but in some, like ursids, they } \\
\text { can display a rostral entotympanic which can } \\
\text { remain unfused and not visible external to the } \\
\text { auditory bulla (Hunt, 1974). }\end{array}$ \\
\hline $\begin{array}{l}\text { Tuba auditiva, Tubae auditivae } \\
\text { (Auditory tube) } \\
\text { (Gray, 1913; NAV, 2017; IVAN, } \\
\text { 2018) }\end{array}$ & $\begin{array}{l}\text { Eustachian tube } \\
\text { (Gray, 1913; Thomassin et } \\
\text { al., 2008; Loza et al., 2015) } \\
\text { Tuba pharyngotympanica } \\
\text { (Thomassin et al., 2008) } \\
\text { Pars tympanica, Pars } \\
\text { escamosa, Pars petrosa } \\
\text { (Loza et al., 2015) }\end{array}$ & $\begin{array}{l}\text { The tube that connects the middle ear to the pharynx } \\
\text { (IVAN, 2018). }\end{array}$ \\
\hline $\begin{array}{l}\text { Pars endotympanica } \\
\text { (Caudal entotympanic bone) } \\
\text { (Hunt, 1974; NAV, 2017; IVAN, } \\
\text { 2018) }\end{array}$ & $\begin{array}{l}\text { Endotympanic bone } \\
\text { (= combined caudal and } \\
\text { rostral entotympanic) } \\
\text { (Loza et al., 2015) } \\
\text { "caudal entotympanic" } \\
\text { (Ivanoff, 2001; 2007) } \\
\text { Caudal entotympanic } \\
\text { (Van der Klaauw, 1922; } \\
\text { Hunt, 1974) } \\
\text { Metatympanic(Wincza, 1896) } \\
\text { Entotympanic (Mivart, 1881; } \\
\text { Van Kampen, 1905) } \\
\text { Piece of hyaline cartilage } \\
\text { (Flower, 1869) } \\
\text { Mastoidien } \\
\text { (Straus-Durckheim, 1845) } \\
\text { Untere Ring (Dieterich, 1841) } \\
\text { Untere Stücke (Hagenbach, } \\
\text { 1835) }\end{array}$ & $\begin{array}{l}\text { Ossifies from cartilage and not from dermal bone } \\
\text { like the ectotympanic. The caudal portion has only } \\
\text { been proven in ursids (Hunt, 1974). }\end{array}$ \\
\hline
\end{tabular}


Continued Table 1:

\begin{tabular}{|c|c|c|}
\hline Terms Used in this Paper & $\begin{array}{l}\text { Previously Used } \\
\text { Synonyms }\end{array}$ & Definition \\
\hline $\begin{array}{l}\text { Os zygomaticum } \\
\text { Zygomatic bone, zygoma } \\
\text { (NAV, 2017; Dechow and Wang, 2017; } \\
\text { IVAN, 2018; Hermanson et al., 2020) }\end{array}$ & $\begin{array}{l}\text { Jugal bone } \\
\text { (Romer and Parsons, 1986; } \\
\text { Kardong, 2009) }\end{array}$ & $\begin{array}{l}\text { In mammals, the appropriate term for this bone } \\
\text { is zygomatic. The use of the term jugal should } \\
\text { only be for amphibians, reptiles, and birds } \\
\text { (NAV, 2017; Dechow and Wang, 2017; IVAN, } \\
\text { 2018; Hermanson et al., 2020). }\end{array}$ \\
\hline
\end{tabular}

${ }^{\star}$ Denotes other equivalent terms to those used in this paper.

sea lions), and Odobenidae (walruses) exhibit specialized aquatic auditory morphologies. Most other carnivores are strictly terrestrial and therefore have auditory characters that reflect transmitting air-borne sound efficiently. For improved hearing, terrestrial mammals use acoustic impedance matching to equal the pressure both in the middle/inner ear and the outside environment, allowing for the consistent flow of sound through the auditory apparatus (Repenning, 1972; Kastak and Schusterman, 1998; Nummela et al., 2007; Nummela, 2008; Reichmuth et al., 2013). Details of the complexities of impedance matching and biomechanics of the terrestrial mammalian ear have been explored (Hemilä et al., 1995; Nummela, 1995; Nakajima et al., 2005; Nummela et al., 2007; Puria and Steele, 2010; Mason, 2016), but the comparisons to the specialized semiaquatic ear remain enigmatic.

Cetaceans (whales and dolphins) on the other hand, are completely aquatic mammals and possess characters that aid in hearing in a strictly water environment (Ketten, 1992; Berta and Adam, 2001; Nummela et al., 2007). Pinnipeds are characterized as semiaquatic, spending time both on land and in the water, therefore their ears must accommodate sufficiently in two types of acoustic media. This is unusual for mammals (Repenning, 1972; Kastak and Schusterman, 1998; Au and Hastings, 2008; Nummela, 2008; Reichmuth et al., 2013; Smodlaka et al., 2018). Pinnipeds are thought to hear airborne sound as do other terrestrial mammals when out of water and use engorged cavernous tissue when underwater to remedy the impedance matching issue (Repenning, 1972). Recently, Smodlaka et al. (2018) suggested that specialized diving adaptations in northern elephant seals do not allow for efficient aerial hearing because the external acoustic meatus of this large mammal is not very conducive to pass sound transmission directly to the tympanic membrane. The hypothesis is that while elephant seals are land bound, seismic vibrations travel through the soft tissues of their body and stimulate the inner ear directly rather than through the ear canal.

As descendants of terrestrial carnivores, the auditory apparatus of the three living groups of pinnipeds reflect their origins, even with secondary adaptations to the aquatic environment. Morphological differences exist among pinnipeds, with otariids having more terrestrial like auditory characters (also reflected in their lifestyle); phocids exhibiting derived aquatic characters, and odobenids possessing a mixture of both types.

\section{Comparisons of Pinniped Auditory Structures}

\section{External Ear and Relevant Basicrania}

Out of the three living groups of pinnipeds, phocids lack a true external pinna (fig. 4, A; Au and Hastings, 2008; Korestsky et al., 2016). Odobenids possess an external 'ear flap' but no true external pinna because there is no cartilage around their external auditory orifice (fig. 4, C; Kastelein et al., 1996 a).

Otariids are the only group of pinnipeds that still retain an external pinna (fig. 4, B), although it is much reduced in size compared to terrestrial carnivores and it can fold upon itself during diving (Repenning, 1972). Sea otters (Enhydra lutris) are also known to 'roll' their external pinnae closed to protect their middle ears when they dive (Ghoul and Reichmuth, 2014). The reduced size and fusiform shape of the external pinna of an otariid 
aids in minimizing hydrodynamic drag. This increases the animal's swimming ability, and the fluid passing around the organism's body creates less noise and turbulence ( $\mathrm{Au}$ and Hastings, 2008; Kardong, 2009). Because the other two families of pinnipeds lack an external pinna, they experience no acoustic-related turbulence or drag underwater. The tradeoff for phocids and odobenids for lacking an external pinna on land is a loss of directional sensitivity to anterior-posterior sounds and an inefficiency to minimize ambient noise (Au and Hastings, 2008). It is unclear why otariids have retained external pinnae while phocids and odobenids have lost theirs. It is possible that the retention of these external structures help otariids with pup recognition in mass populated rookeries (discussed further below; Riedman, 1990; Kastak and Schusterman, 1998; Marsh, 2001).

Most eutherians exhibit pinnae as this is exclusively a mammalian trait, but pinnipeds, cetaceans, and moles lost theirs secondarily (Berta and Adam, 2001; Au and Hastings, 2008). Specialized auditory mechanisms have been developed, such as echolocation in cetaceans and extremely sensitive mechanoreception in moles (Kardong, 2009). Use of a different sensory system coupled with a need to reduce hydrodynamic drag is a possible reason for the loss of external pinnae in pinnipeds (Au and Hastings, 2008; Kardong, 2009).

All pinnipeds still possess an external acoustic meatus that has some cavernous tissue which is thought to expand during diving (which will be discussed below; Repenning, 1972; Wyss, 1987; Kastelein et al., 1996 a; Smodlaka et al., 2018). Some pinnipeds, specifically phocids, can have more tortuous and very narrow passageways limiting hearing on land (Kastak and Schusterman, 1999; Smodlaka et al., 2018). Smodlaka et al. (2018) suggested that the very narrow external acoustic Meatus of the northern elephant seal is so specialized for deep diving that it probably does not function for hearing on land. Instead, sound travels as seismic vibrations through other portions of the seal's body until it reaches the inner ear directly.

The opening of the external acoustic meatus in phocids as well as parts of the auditory canal contain cartilage and associated musculature (Kastak and Schusterman, 1998). A study by Kastelein et al. (1996 a) examined the soft tissue around the auditory region of the walrus (Odobenus rosmarus) and found that the outer ear passage, although supported by cartilage, has auricular musculature that closes the external acoustic meatus when diving. They were not sure what mechanism controls the closure of the external orifice, but in the harp seal (Pagophilus groenlandicus) it has been suggested they can actively control the closure (Møhl and Ronald, 1975). Overall, it seems the canals and external orifices of phocids and odobenids collapse during diving and otariids can fold up their external pinnae to close their meatuses (Repenning, 1972; Riedman, 1990; Kastelein et al., $1996 \mathrm{a}$; Kastak and Schusterman, 1998; Au and

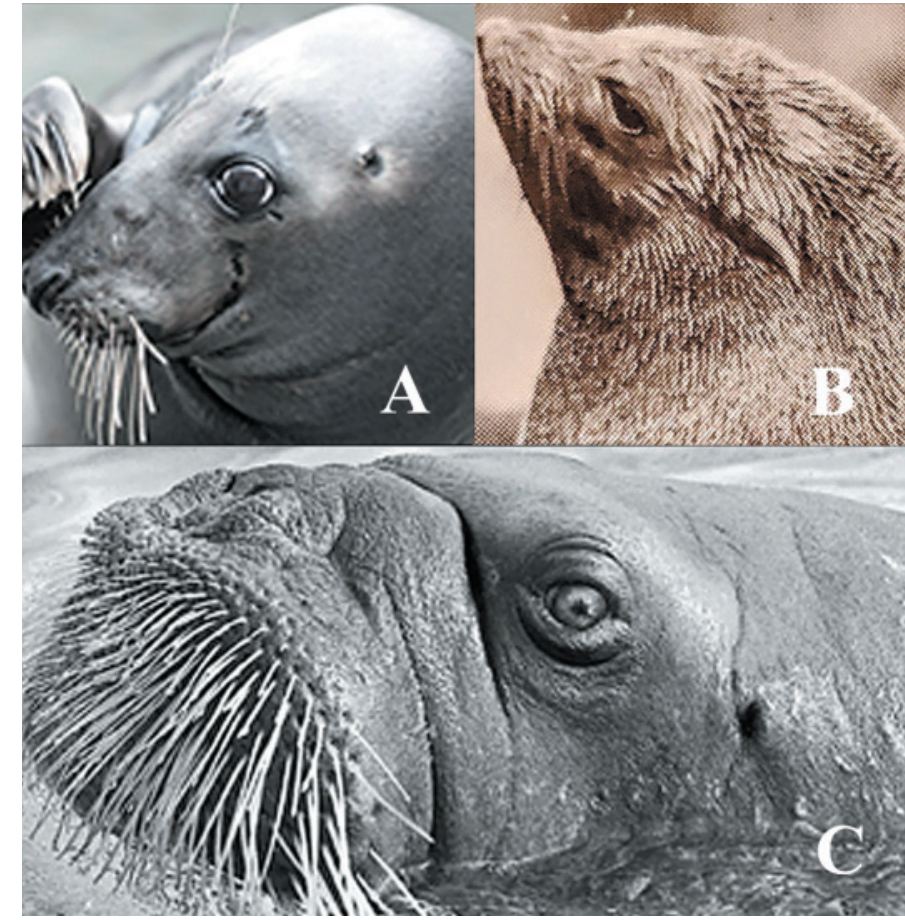

Fig. 4. External Pinnae of Pinnipeds: A - Phocid; B - Otariid (modified from Nowak, 1991); C - Odobenid (modified from Kastelein et al., 1996 a). 
Hastings, 2008). These studies mentioned above have investigated the mechanism that signals auditory closure as well as other body system changes during diving, but none have come to any definitive conclusions.

The auditory bulla in pinnipeds is one of the more diagnostic structures in determining family-level classification. The hyper-inflated phocid bulla compared to the moderately flattened bulla of an otariid or odobenid (fig. 5, A-C, E) is considered a strong phylogenetic signal (Wyss, 1987; Cozzuol, 2001; Koretsky and Holec, 2002; Berta et al., 2006; Berta and Churchill, 2012; Boessenecker and Churchill, 2015; Koretsky and Rahmat, 2015; Koretsky et al., 2016).

All representatives of the family Phocidae (true seals) have inflated auditory bullae in contrast to other pinnipeds, with varying degrees of inflation (fig. 5, A, E). There has been some exploration of the function of such an inflated bulla only in phocids but nothing definitive other than the suggestion of a possible deep diving adaptation (Koretsky and Rahmat, 2015; Loza et al., 2015). It is hypothesized that since phocids are overall the deepest divers of the pinnipeds, the inflation of the bulla has more to do with pressure regulation at immense depths rather than hearing underwater.

Previous studies that have tried to identify the controlling factor for auditory bulla size (i. e. amount of inflation) focused on rodents and more recently felids (Hunt, 1974; Huang et al., 2002; Yazdi et al., 2015). These studies showed that the environment and humidity levels can influence the hearing acuity of a mammal. For example, in an environment with decreased humidity levels, mammalian hearing can be impacted negatively because low frequency sounds are absorbed rather than transmitted; to counteract the low humidity absorption, middle ear cavities increase in volume by external inflation of the auditory bulla. This is the proposed reason for desert-dwelling rodents and felids having hyper-inflated

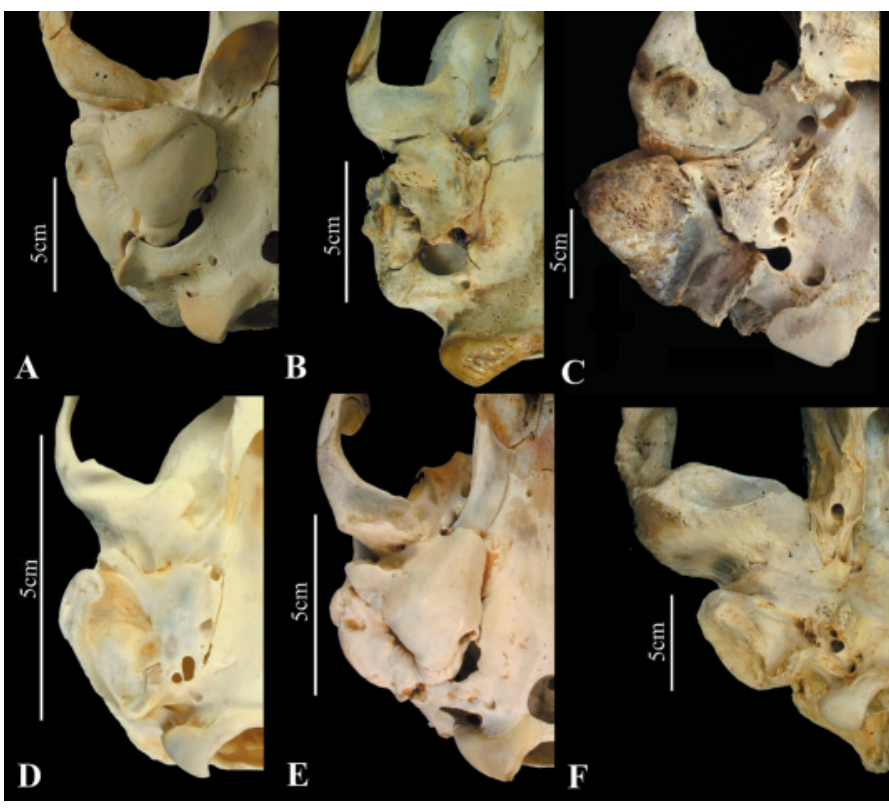

Fig. 5. Auditory Bulla Inflatedness. Ventral views of right basicrania of: A - Cystophora cristata, MWNH 187 from Museum Wiesbaden of Natural History; B - Eumetopias jubatus, UWBM 12551 from University of Washington Burke Museum; C - Odobenus rosmarus, UAM 14793 from University of Alaska Mammals; D - Lontra candadensis, UWBM 32217 from University of Washington Burke Museum; E - Phoca vitulina, UWBM 51215 from University of Washington Burke Museum; F - Ursus arctos, UWBM 39422 from University of Washington Burke Museum (modified from https://virtual.imnh.iri.isu.edu). bullae (Hunt, 1974; Huang et al., 2002; Yazdi et al., 2015). Therefore, varying degrees of auditory bulla inflation exhibited by terrestrial carnivores could be due to the diverse environments they inhabit and may also be influenced by the surrounding musculature for the external pinna (Huang et al., 2002; Yazdi et al., 2015). These lines of evidence do not apply as to why there are degrees of inflation seen in semiaquatic mammals like phocids. These mammals do not need to worry about humidity levels to hear efficiently, on land or in the water, and since they do not have external pinnae, they do not have extensive musculature in this region. Even some of the earliest phocid fossils, such as Devinophoca, exhibit fairly derived or inflated auditory bullae (Koretsky and Rahmat, 
2015), but this needs further investigation.

Hunt (1974) observed and categorized carnivores based on the external morphology of the auditory bulla. He noted that bulla hypertrophy was not always the primary cause of an enlarged middle ear cavity. Sometimes when the bulla did not appear as inflated, the middle ear cavity itself had invaded the surrounding cranial bones, most commonly the mastoid. Even without an enlarged auditory bulla, the animal could have increased hearing acuity in

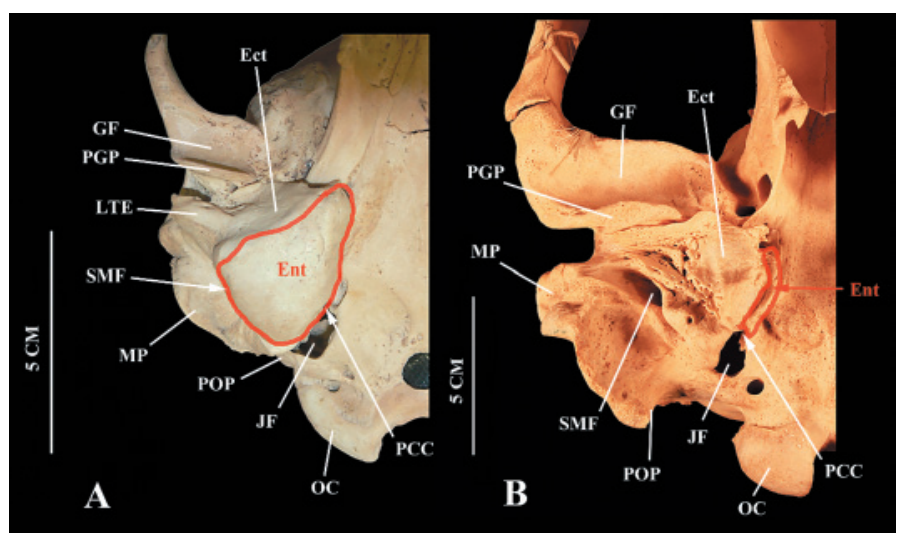

Fig. 6. Pinniped Basicrania: A - Phoca vitulina; B - Otaria flavescens. Ect - ectotympanic; Ent - entotympanic and red outline; GF - glenoid fossa; JF - jugular foramen; LTE - lateral portion of tubercle of the ectotympanic; MP - mastoid process; OC - occipital condyle; PCC - posterior opening of the carotid canal; PGP — postglenoid process; POP — paroccipital process; SMF — stylomastoid foramen. more arid environments (Repenning, 1972; Hunt, 1974).

Hunt (1974) also included pinnipeds in his study of modern carnivores and their morphologies. Previously, Doran (1878) informally had pinnipeds closely related to but not within the Carnivo-ra. However, Tedford's (1976) examination of the morphologies of dentition and the basicranium showed that pinnipeds appear to be more closely related to arctoids (ursids, mustelids, and procyonids) than they are to the feliforms (felids, hyaenids, viverrids) or cynoids (canids).

Hunt (1974) categorized carnivorans based on the arrangement of two bonyelements: the ectotympanic and the caudal entotympanic. Throughout the rest of this paper, especially for pinnipeds, the caudal entotympanic will be referred to as the entotympanic (fig. 6, 7). The ectotympanic forms the anterolateral portion of the bulla and forms a ring internally that supports the tympanic membrane. The entotympanic forms the posteromedial section of the bulla and houses the pathway of the internal carotid artery (fig. 7, A; Hunt, 1974; Tedford, 1976). There is a third contribution to the bulla, the rostral entotympanic, which resides internally but cannot be seen unless the auditory bulla is removed. Hunt (1974) undertook a descriptive

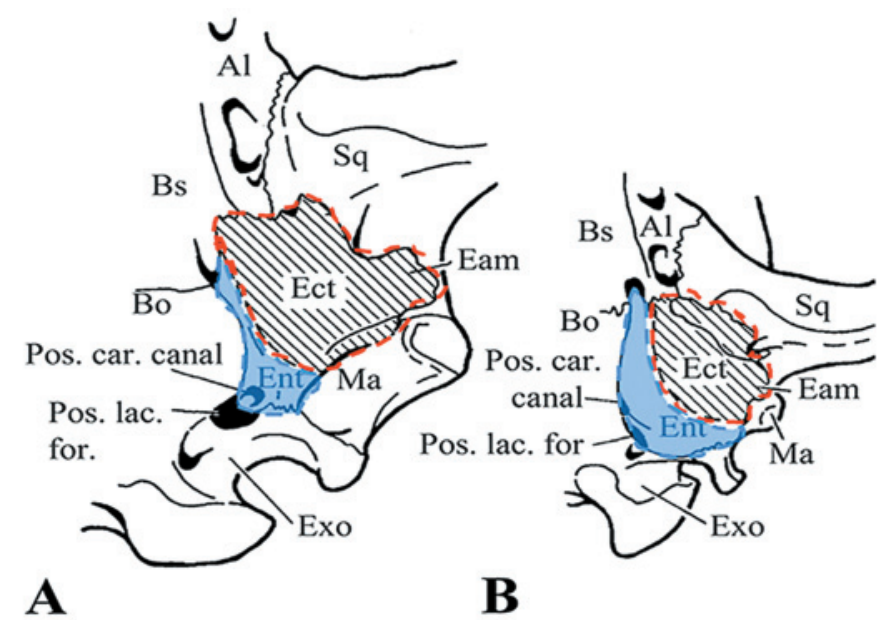

Fig. 7. Representative Carnivore Basicrania of Types of Auditory Bullae: A - Ursus, representation of Type A; B - Canis, representation of Type B (one third the scale). Al - alisphenoid; Bo - basioccipital; Bs - basisphenoid; Eam - external auditory meatus; Ect - ectotympanic, outlined with red dotted line; Ent - rostral + caudal entotympanic, marked with blue; Exo - exoccipital; Ma - mastoid process of petrosal; $\mathrm{P}$ - promontorium; $\mathrm{Sq}$ - squamous portion of temporal bone; pos. car. - can. posterior opening of the carotid canal; pos. lac. for. - posterior lacerate foramen which is known as the jugular foramen (modified from Tedford, 1976). 
analysis of the auditory bulla and organized the carnivores into five types: A, B, C, D, and E. The morphology exhibited by pinnipeds fits into types $A$ and $B$, which will be the main focus of this study.

The Type A auditory bulla (fig. 7, A: Ursidae, Ailurus, Otariidae, Odobenidae, Lutrinae and Mephitidae) is believed to represent the most primitive state of the living Carnivora. The bulla is made up mostly of ectotympanic in comparison to the rostral entotympanic and the caudal entotympanic. Ursids even exhibit two caudal entotympanics (E1 and E2) that eventually fuse together. There is no extension of the middle ear cavity into the internal region of the mastoid process. This is thought to be due to lack of caudal entotympanic inflation. The bulla is single chambered with no septum bullae (Hunt, 1974). Wyss (1987) reviewed the Odobenidae designation of Type A and observed a similar arrangement of the entotympanic and ectotympanic portions of the bulla.

The Type B (fig. 7, B: Canidae, Phocidae, Procyonidae, Mustelinae, Guloinae, and Melinae) bulla is single-chambered but contains pseudoseptae than can partially divide the cavity. These smaller areas within still communicate freely. This bulla is similar to Type A but exhibits varying degrees of inflation in the single caudal entotympanic. As a result, this bony component appears to contribute more to the overall bulla structure. The caudal entotympanic has a characteristic ' $L$ ' shape. The representative family for this bulla type is Canidae, and some of the observations, like the pseudoseptae, made by Hunt (1974) cannot be applied completely to Phocidae. Types C-E belong to carnivores that are hyenid or felid-like, with some major differences from the previous two types of auditory bullae. The construction of the pinniped bullae has been studied by comparing changes through ontogeny in the South American sea lion (Otaria byronia) and the southern elephant seal (Mirounga leonina) (Loza et al., 2015; 2018). These studies focused on the difference between the distribution of entotympanic and ectotympanic bones and noted the sexually dimorphic differences in the adults.

The mastoid process is generally large in arctoids, creating a greater surface area for muscle attachment (fig. 6). Wyss (1987) observed that the mastoids of both phocids and otariids are roughly the same size. The phocid mastoid process tends to appear larger and rounder resulting from pachyostosis (swollen bone). The living walrus also has a larger mastoid process which appears to be a recent development compared to its fossil precursors that have the 'typical' terrestrial knob-like appearance. It has been hypothesized that an enlarged mastoid process can help with different types of aquatic hearing. Terrestrial studies have found that enlarging the space within the mastoid process can be recruited to aid in hearing acuity, as in skunks (Mephitis mephitis) and badgers (Taxidea taxus), but studies have not provided enough supporting evidence for this in pinnipeds (Hunt, 1974).

The external portion of the mastoid in both modern otariids and odobenids (fig. 6) fuses and creates a complete ventral ridge with the paroccipital process, but this morphology is not seen in ursids or phocids. It is hypothesized that this difference results from the adaptation for conductive reaction or bone conduction in the skull and surrounding basicrania (Repenning, 1972). This fusion allows for the orientation of the bones of the skull to aid in the reflection and direction of sound and this morphology is not observed in other carnivores.

Another pinniped characteristic relates to the decreasing fusion of the petrosum to other skull bones while still remaining attached to the mastoid (Repenning, 1972). Repenning (1972) notes that if pinnipeds use bone conduction, then isolating the petrosum from other cranial bones would prevent interference of extraneous vibrations made by the animal's own body. In the aquatic environment it is harder to localize sound direction but by isolating the petrosum, also seen in cetaceans, sound localization is more efficient (Repenning, 1972; Nummela et al., 2007).

Middle ear 
Overall, phocids have a fairly large middle ear cavity compared to other pinnipeds and some terrestrial carnivores. This possibly helps to minimize the dampening effect on the tympanic membrane as it vibrates in water or equalizes pressure for deep diving (Repenning, 1972). Regardless of function in both phocids and odobenids, there seems to be a correlation between a larger tympanic cavity and the presence of enlarged auditory ossicles and tympanic membrane (which will be discussed below). Otariids have much smaller tympanic cavities in comparison, as well as smaller auditory ossicles. Even though all three families exhibit different sized middle ear regions, they all contain extensive cavernous tissue that engorges when they dive (Repenning, 1972; Wyss, 1987; Kastak and Schusterman, 1998).

All pinnipeds have cavernous tissue throughout their external and middle ear regions, with phocids having the greatest surface area and otariids having the least (Repenning, 1972). Cavernous tissue fills with fluid during diving, decreasing any open space around the tympanic membrane and auditory ossicles. This tissue enlargement helps decrease pressure in the middle ear and enhances the ability to hear underwater by increasing the acoustic impedance matching (Repenning, 1972, Kastak and Schusterman, 1998). By filling the middle ear cavity with 'fluid', the transfer of sound waves can occur continuously from the external aqueous environment to the now aqueous middle ear. This matching of environmental media allows for efficient directing of sound to the inner ear (Repenning, 1972; Purves et al., 2008). Phocids are the most adapted for deep diving by comparing both cavernous tissue extent and other physiological adaptations, such as oxygen retention. Behavioral studies also demonstrate that phocids have the best sensitivity for hearing in water (Repenning, 1972; Reidman, 1990; Kastak and Schusterman, 1998; Marsh, 2001).

Phocids and odobenids have retained larger tympanic membranes (when compared to overall body size), these are similar in size to those of terrestrial carnivores (Repenning, 1972). Retention of a larger tympanic membrane is most likely an adaptation for deep diving but in terrestrial carnivores it is a consistent pattern to have comparable tympanic membrane and middle ear cavity size (Repenning, 1972; Hunt, 1974). Though modern odobenids are considered shallow divers, it is hypothesized that an earlier ancestor (Imagotaria, around early late Miocene) was a deep diver whom this enlarged structure was inherited (Repenning, 1972; 1976; Wyss, 1987). On the other hand, otariids have smaller tympanic membranes compared to body size; this most likely evolved as another way of dealing with diving pressures. The smaller the space and the tympanic membrane, the less strain and need to equalize pressure at deeper depths (Repenning, 1972).

Another area of increased size, even among otariids, is the oval window. All three families of pinnipeds have larger oval windows compared to terrestrial carnivores of similar body size, even if the tympanic membrane is not comparably as large (Repenning, 1972). Both structures are compared by using a ratio of the tympanic membrane to oval window size and the typical terrestrial carnivore range is from $35: 1$ to $50: 1$. The range is approximately $38: 1$ for phocids and closer to $10: 1$ for odobenids and otariids. The smaller size ratio seen for pinnipeds, especially the deeper divers, might be a protective measure against the high pressures of diving. Repenning (1972) suggests that this ratio of tympanic membrane size and oval window size can vary due to optimum diving depth for feeding.

All pinnipeds have a round window fossula (also known as fossula fenestrae cochlea; Buchcanan, 1907) which is a depression in which the aperture of the round window can be found (Buchanan, 1907; Repenning, 1972). The oval window also can be found within a fossula but the stapes rests on top of this area obscuring it from view. Phocids seem to have the most developed round window fossula and otariids the least (Repenning, 1972; Wyss, 1987). This larger depression is most likely exhibited in these specific pinnipeds to prevent the cavernous tissue from extending too far and inhibiting the expansion of the round window membrane (Repenning, 1972). There is no pictorial representation of the round 
or oval window fossulae in pinniped publications, so any descriptions or definitions have come from human-based anatomy sources.

All pinnipeds have larger round windows. This is an adaptation to receive more intense sound through the ossicular chain during underwater hearing (Repenning, 1972; Smodlaka et al., 2018). In typical land carnivores, the size ratio of the round and oval windows is $1: 1$ but in pinnipeds it is closer to $3: 1$. This size difference in the windows seems to help with amplifying sound reception by way of the ossicular chain in an aquatic medium (Repenning, 1972). There is an opening observed in many phocids but no other carnivores, that allows the secondary tympanic membrane that covers the round window to expand external to the skull. This opening, known as the external cochlear foramen, is found at the posterior junction of the mastoid and the auditory bulla. Only some phocids have this foramen, which is an adaptation specific to hearing in the aquatic environment because it helps to dissipate the increased intensity of sound (Repenning, 1972; Nummela et al., 2007; Smodlaka et al., 2018). Amson and de Muizon (2014) noted that the external cochlear foramen is not easily observed in all phocids, and a structure known as the mastoid lip, commonly identified in Lobodontini, obscures the opening (page 531). Our observations in several skulls from

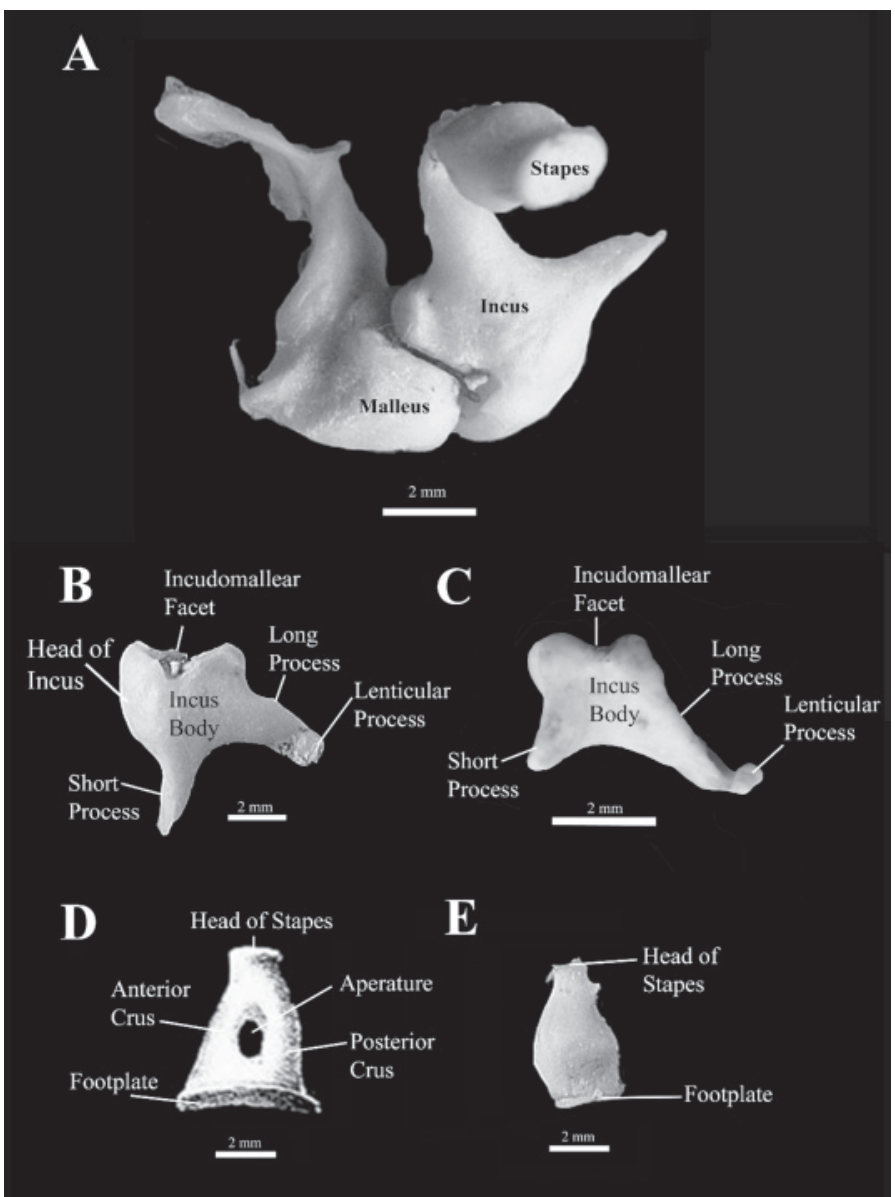

Fig. 8. Auditory Ossicles: A - The articulated ossicles of the left ear of a 2 -year-old male Pacific walrus, medial view (modified from Kastelein et al., 1996 a); B - Odobenus rosmarus incus, medial view (modified from Kastelein et al., 1996 a); C - Juvenile Ursus martimus incus, medial view; D - Drawing of Phoca vitulina stapes (modified from Doran, 1878); E - Odobenus rosmarus stapes, dorsal view (modified from Kastelein et al., 1996 a). the osteological collection at the Smithsonian Museum Support Center shows that the mastoid lip overhangs the foramen.

In fissiped carnivores, both the phocid and odobenid ossicular chains are greatly enlarged (Doran, 1878; Repenning, 1972; Wyss, 1987). This enlargement includes all three ossicles: stapes, incus, and malleus (fig. 8, A). A standard set of otariid ossicles are about the same size as a typical land carnivore, but the difference is that an otariid has a much smaller tympanic membrane (Repenning, 1972). The enlarged size of all the auditory ossicles in phocids and odobenids is hypothesized to be completely functionally based (Repenning, 1972; Nummela, 1995; Nummela et al., 2007; Smodlaka et al., 2018), allo-wing these pinnipeds to have better acoustic sensitivity underwater. Even though they may hear very well underwater it seems that pinnipeds hear about as well as humans do in air (Kastak and Schusterman, 1998; Nummela et al., 2007; 
Reichmuth et al., 2013; Ghoul and Reichmuth, 2014; Smodlaka et al., 2018).

Odobenids show a mixture of phocid and otariid features and adaptations. For instance, they have phocid sized ossicles, but these are shaped like an otariid's. The overall size of otariid ossicles fall in the same range of similar sized carnivores (Repenning, 1972). Marsh's (2001) study examined the morphology, weight, and density of the ossicular chain with only low- resolution images for comparison.

Only three sets of phocids ossicles were presented, only in one view, and not labeled. However, information provided on weights and density of the ossicles were insightful to determine hearing capabilities. To date, there are no modern sources that discuss or describe the ossicles of all pinnipeds and compare them to the terrestrial carnivores. There are online databases, such as Digimorph and Morphosource, that possess 3-D renderings of carnivore skulls. None of these reconstructions are detailed enough to display ossicles, so there is much yet to be done in this area of analysis.

The malleus (fig. 9) is thought to show a strong phylogenetic signal for mammals and therefore is often included in phylogenetic studies (Ekdale, 2015; Loza et al., 2018 a). One of the structures on the malleus that is considered to have a phylogenetic signal for pinnipeds is the rostral process. Wyss (1987) looked at walrus ossicles, focusing on the malleus, but his images were very few and did not provide enough context to compare with other descriptive works. Wible and Spaulding (2012) established that in situ imaging of the malleus is important to getting an accurate representation of the morphology. Most often, ossicles can break during the preservation process of specimens, especially along certain fault lines in the bones and can give incorrect information. Some groups of mammals are hierarchically organized by morphology of their ossicles so a review of the mallei of carnivores is needed to conclude accurate representations for comparative purposes. There have been more recent studies that have cited Wible and Spaulding (2012) but have not mentioned or attempted to reevaluate the carnivore mallei.

The typical terrestrial carnivore malleus (fig. 9, F, I) is characterized by a small anteriorly convex head (except ursids (fig. 9, F) and some procyonids), a long thin manubrium, a strong muscular process (site of the tensor tympani m.) except in ursids, a well-developed lateral process, and a broad thin lamina extending between the slender rostral process and the region of the head and neck (Doran, 1878; Wyss, 1987). According to Wyss (1987), all pinniped mallei (examples seen in figs 9, A-E, $\mathrm{G}-\mathrm{H}$ ) lack a pit for the insertion of the tensor tympani muscle (it originates from the auditory tube), exhibit loss of the muscular process, show a reduction of the rostral process and osseous lamina, tend to exhibit an anterior concavity on the malleolar head, and have a shortened manubrium. Only phocids and odobenids exhibit an infinity shaped articulation surface (fig. 9, B-E, G-H) on the head (Wyss, 1987; Kastelein et al., 1996 a; Loza et al., 2015).

The incus (fig. 8, B-C) is greatly enlarged in phocids and odobenids (Doran, 1878; Repenning, 1972; Wyss, 1987; Kastelein et al., 1996 a). In terrestrial carnivores the incus typically is smaller in comparison to the malleus, but this is not the case for phocids and odobenids (Doran, 1878). The incus does not vary as much among carnivoran families except for the length of the short process. In phocids, and to a lesser degree odobenids, the incus also has an enlarged 'head' (Repenning, 1972; Wyss, 1987). This head is just dorsal to the short process (fig. 8, B). It attaches to the articulation surface on the malleus that tends to show much variation across both terrestrial and aquatic carnivores (Repenning 1972; Wyss 1987; Bastl et al., 2017; Loza et al., 2018 a). Ossicle size aids in acuity of underwater hearing, but the enlarged head of the incus specifically offsets the balance of the ossicular chain, making it more easily stimulated to move or more sensitive to sound vibrations through axial rotation (Repenning, 1972). In a more recent study of the incus of some felids, canids, and hyenids, it was established that the morphology of 
the articular facets could be used for classification of carnivores at the family level (Bastl et al., 2017). This same study also identified a stronger likelihood that the characters of the malleus help to determine ecology and the characters of the incus help to determine phylogeny.

The stapes is not very distinctive among carnivoran families (Doran, 1878) and there is much less information regarding this auditory ossicle. The main difference observed is whether the stapes has a visible aperture (fig. 8, D-E). Many phocids seem to retain a visible aperture whereas odobenids do not. There is little information regarding otariid stapes in the current literature. Otherwise, like the other phocid and odobenid ossicles, the stapes is larger than in a typical terrestrial carnivore of the same body size (Doran, 1878; Repenning, 1972; Wyss, 1987).

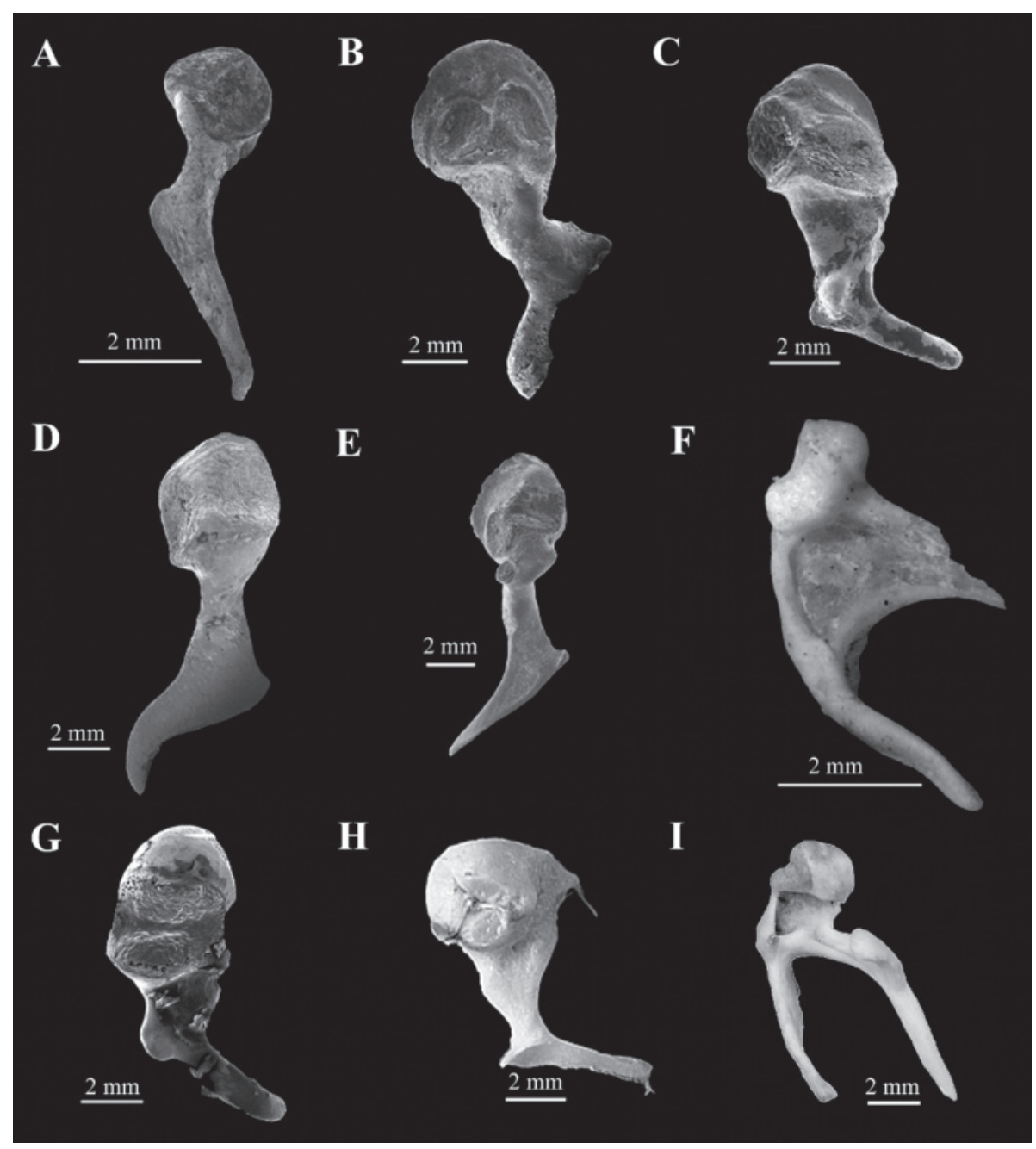

Fig. 9. Carnivore Malleus: A - Right, posterior view of Arctocephalus gazella; B - Left, posterior view of Mirounga leonina; C - Right, posterior view of Leptonychotes weddellii; D - Left, posterior view of Lobodon carcinophaga; E - Left, posterior view of Phoca vitulina; F - Right, medial view of Ursus martimus; $\mathbf{G}$ - Right, posterior view of Ommatophoca rossii (modified from Loza et al., 2018 a); H - Left, posterior view of Odobenus rosmarus (modified from Kastelein et al., 1996 a); I - Left (but reversed from right side), medial view of Panthera pardus (modified from Wible and Spaulding, 2012). 


\section{Inner ear}

The morphology of the inner ear structures reflect an abundance of information about an organism's ecology. The shape and whorls of a cochlea can indicate whether a mammal hears more easily at low or high frequencies, even though the most accurate identifier of frequency is the length of the basilar membrane of the cochlea (Ekdale, 2013, 2015). Generally, higher frequency processing occurs at the proximal portion of the cochlear whorl, right at the junction of the oval window and movable stapes. Lower frequencies are processed at the terminal end of the cochlea and some studies have discovered this shape difference based upon frequency range (Ekdale, 2015). The cochlea is where the sound is processed for all carnivores regardless if the sound was transferred through an aerial or an aquatic medium (fig. 2; Repenning, 1972; Kardong, 2009).

There has been limited research on the morphology of pinniped cochlear shape and size in comparison to other terrestrial mammals (Repenning, 1972; Loza et al., 2018 b). Repenning (1972) noted a varied direction of the basal whorl for phocids in general. The basal whorl of the cochlea has a more transverse orientation in the skull compared to that of odobenids, otariids, and other terrestrial carnivores in which runs posterolaterally. This is thought to help with sound directionality as it first enters the cochlea. By the distal end of the cochlea, the phocid structure resembles that of all other carnivores. The direction of the basal whorl of the cochlea predicts an animal's ability to take in sound because of the linkage to the ossicular chain. If an organism cannot direct sound waves to its cochlea in the most efficient manner, its hearing acuity is diminished (Repenning, 1972; Ghoul and Reichmuth, 2014). Another difference all pinnipeds exhibit is that the portion of the scala tympani located behind the round window has more volume (Repenning, 1972). Overall, the previous behavioral studies have not focused on this observation of varying cochlear direction and how phocids optimally receive sound.

A more recent set of generalized studies of mammals discussed the cochlear whorl size and number: the larger the circumference of the basal whorl the more likely the animal focused on higher frequencies (Ekdale, 2013, 2015). In all mammals the higher frequencies are processed at the base of the cochlea and the lower frequencies are processed at the apical portion (Kardong, 2009; Ekdale, 2013, 2015). These studies assessed a wide range of mammals including some mustelids, a few canids and an otariid. These animals possess different frequency ranges and these studies looked at the circumference of the basal whorl compared to observed hearing ability (Ekdale, 2013). Because these studies only included one otariid specimen, there is not enough information to determine pinniped structure or variability (fig. 10). Loza et al. (2017) looked at some southern hemisphere phocids in comparison to Ommatophoca rossii (Ross seal) and noted that these pinnipeds all have about two whorls to their cochlea.

The other main structures of the inner ear are the semicircular canals (fig. 2). Many studies hypothesize that the overall shape and circumference of the semicircular canals can aid in determining aquatic or terrestrial habits as well as locomotion patterns (Ekdale, 2013, 2015; Grohé et al., 2016). It has been suggested that in semiaquatic to fully aquatic mammals, the lateral semicircular canal has the largest circumference when compared to terrestrial mammals, whose largest semicircular canal is either the anterior or posterior canal (Ekdale, 2013; Grohé et al., 2016). The reasoning behind this is that animals on land constantly are stimulated in the anterior-posterior direction while organisms in the aquatic environment might be stimulated more often in medial-lateral directions. A study with Mustelidae using CT scans (Grohé et al., 2016) observed slight differences in the shape of these semicircular canals between semiaquatic and terrestrial species. 


\section{Current Studies of Pinniped Hearing}

The current trend in the study of pinniped hearing is to incorporate behavioral studies of live, trained animals. These studies attempt to observe the hearing capabilities of pinnipeds to understand how these organisms hear both in water and on land. These results are displayed in the form of an audiogram which quantitatively measures an animal's ability to register the intensity and frequency of sound within their audible range. Therefore, pinniped auditory data can be compared to other semiaquatic and terrestrial carnivores.

For example, Kastak and Schusterman (1998) focused on measuring the auditory reactions of a single trained phocid, odobenid, and otariid, in both open air and underwater settings. By establishing the upper and lower frequency ranges of all three animals, this study indicated that otariids (a female California sea lion in this case) had better sensitivity in the aerial environment (Reidman, 1990; Kastak and Schusterman, 1998; Marsh, 2001). As discussed above, this retention of aerial hearing efficiency is hypothesized to be used for pup rearing in mass populated rookeries. Besides possessing better directional hearing, otariids also seem to be able to discern specific aerial sounds within ambient noise with more acuity than the other pinnipeds (Ghoul and Reichmuth, 2014). Phocids seem to be the most aquatically adapted, acoustically speaking, because they can register higher frequencies at lower intensities under the water in comparison to the other pinnipeds (Kastelein et al., 1996 b; Reichmuth et al., 2013; Ghoul and Reichmuth, 2014; Cunningham and Reichmuth, 2016).

Other acoustic studies such as those by Ghoul and Reichmuth (2014), incorporated previous pinniped audiograms and compared that information to other carnivores such as
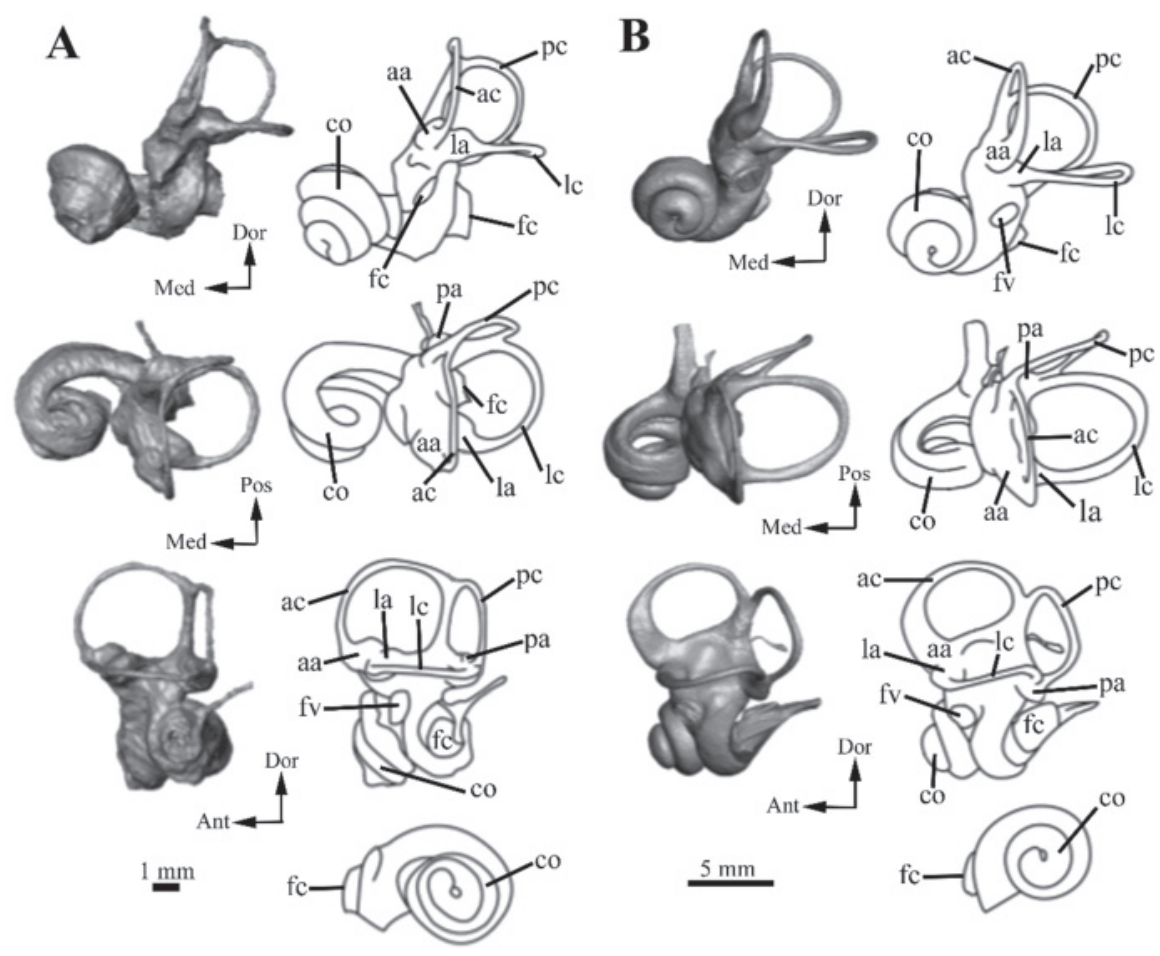

Fig. 10. CT Scans and Reconstructions of the Inner Ear: A - Canis familiaris; B - Eumetopias jubatus with directional labels as follows: Ant — anterior; Dor — dorsal; Med — medial; Pos — posterior. Anatomical labels are: aa — anterior ampulla; ac — anterior semicircular canal; co — cochlea; fc — fenestrae cochleae; fv — fenestrae vestibuli; la — lateral ampulla; lc - lateral semicircular canal; pa - posterior ampulla; pc — posterior semicircular canal (modified from Ekdale, 2013). 
the sea otter (Enhydra lutris). This study presented an adaptation gradient in hearing ability from completely terrestrial carnivores to derived semiaquatic carnivores. The audiograms demonstrated that sea otters did not hear as well underwater as phocids, and heard higher frequencies in air than phocids and odobenids, just not as well as terrestrial carnivores (Ghoul and Reichmuth, 2014; Cunningham and Reichmuth, 2016).

For more detailed explanations on the different kinds of audiogram and acoustic studies that focus on pinnipeds, please refer to: Hanggi and Schusterman (1994), Hemilä et al. (1995), Kastelein et al. (1996 b), Kastak (1997), Kastak and Schusterman (1999), Mossbridge and Thomas (1999), Kastelein et al. (2002), Holt et al. (2004), Holt et al. (2005), Kastelein et al. (2005), Hemilä et al. (2006), Bodson et al. (2007), Holt and Schusterman (2007), Kastelein et al. (2009), Jones et al. (2014), Reichmuth et al. (2013), Cunningham et al. (2014), Sills et al. (2014), Sills et al. (2015), Byl et al. (2016), Cunningham and Reichmuth (2016), and Lucke et al. (2016). A few other acoustic studies that focus more on terrestrial mammals include Heffner and Heffner (1982), Heffner et al. (2001), Huang et al. (2002), Barklow (2004), and Heffner and Heffner (2007).

The consensus of most of these behavioral studies (mentioned above) find that pinnipeds exhibit lessened acoustic sensitivity in an aerial setting when compared to other terrestrial carnivores. They are still equivalent in hearing ability to that of humans in detecting sound in the aerial environment at the same normal human frequency ranges (20-20,000 hz; Reidman, 1990; Cutnell and Johnson, 1998). The next step for these studies would be to include the anatomy of the auditory apparatus. Almost all of these studies neglect to mention any morphology that would reflect the hearing function observed from the audiograms.

\section{Discussion}

The function of auditory structures needs to be assessed for both terrestrial and semiaquatic carnivores to establish the patterns of morphology that are present in transitional species. There is relevant functional information from current auditory studies with live animals, but these studies do not include any internal anatomy or functional morphology. Even though studies have shown pinnipeds have the ability to hear efficiently both in air and water, there is very little information how all pinnipeds accomplish this feat based on the internal anatomy of their ears. Only the northern elephant seal has a mechanism suggested for how they hear in the aerial versus the aquatic setting (Smodlaka et al., 2018).

An example of a structure whose function has not been successfully addressed is the inflated auditory bullae of phocids. It is hypothesized to be a deep diving adaptation (Koretsky et al., 2016), as seen in Mirounga, the deepest diving phocid with one of the largest bullae. However, not all phocids are extremely deep divers even with the presence of hyperinflated bullae. Once the morphology of auditory structures can be associated with specific functions in pinnipeds and other semiaquatic mammals, a better understanding of how these structures evolved can emerge. If an inflated auditory bulla is for deep diving, then it could be hypothesized that more fossil pinnipeds would exhibit inflated bullae as taxa became increasingly more adapted for the aquatic environment. Hypothetically speaking, it is possible that phocids could have retained this inflated structure from their terrestrial ancestor and adapted it to their semiaquatic lifestyle. Currently, it is unknown when or why the auditory bulla became inflated in phocids. The future use of new technology, such as CT scans of fossil and modern species will be beneficial to analyze the morphology of inner and outer ear structures as well as to propose possible hearing capabilities of early pinniped relatives without destructive sampling.

Per Wible and Spaulding (2012), a revaluation of pinniped auditory ossicles, especially the malleus, needs to occur to verify the use of these characters in phylogenetic analyses. The malleus and incus, once described appropriately, could provide valuable information 
about carnivoran phylogenetic relationships and ecological adaptation to hearing in water. Based on previous studies, the malleus may provide more ecological adaptations to hearing in water, whereas the incus may reflect phylogenetic connections to other carnivoran families (Wible and Spaulding, 2012; Bastl et al., 2017; Loza et al., 2018 a). Other areas of exploration include the morphometric analyses of the auditory bullae of all pinnipeds to determine species differences, sexual dimorphism, and functional differences of hearing capability when constrained by diet and hunting strategies.

There have been many technological strides in the acoustic studies of mammals, especially those that primarily dwell in the high frequency range (bats and whales; Ekdale, 2013). The use of CT scans, high resolution imaging, and dissections have helped to increase the knowledge of this area. However, the exploration of the acoustic anatomy in pinnipeds is severely lacking even with all the technological advances. To date, only specialized studies of some species, both terrestrial and aquatic, have been done. Other studies cannot be compared accurately to terrestrial carnivores because of the complications of the terminology (Kastelein et al., 1996 a; Loza et al., 2015; 2018; Smodlaka et al., 2018). The overall morphology of the auditory region of extinct and extant pinnipeds needs to be described and presented pictorially (Smodlaka et al., 2018). This current preliminary review offers a framework for accurate, consistent auditory terminology for different Carnivoran families. Extensive literature research during the writing of this review demonstrated the importance for such a study of the auditory region. Current and planned future studies will attempt to clarify inaccurate terminology with general, high-resolution images of extant and extinct specimens of pinnipeds.

This initial study details the gaps in prior research on the hearing adaptations for transitional semiaquatic carnivores. There is some information regarding hearing behavior of modern pinnipeds and semiaquatic carnivores, but very little can be correlated to morphology. Therefore, none of the behavioral information can be correlated to fossil carnivores. To understand how transitional semiaquatic carnivores could hear in this dual environment, there needs to be a unification of morphology and hearing behavior. Overall, results from this study will aid in establishing and predicting the adaptive patterns (from land to sea) in the basicranial morphology of pinnipeds, especially in phocids.

We would like to thank members of the Laboratory of Evolutionary Biology at the Howard University College of Medicine (Ms. Madelyn Crowell, Dr. Edwin Gilland, and Dr. Daryl Domning) for their advice, expertise, and assistance with this project. Special thanks to the Smithsonian Museum of Natural History specifically the Department of Vertebrate Zoology, Mammals division and Paleobiology for access to all their resources.

\section{References}

Agur, A. M. R. and Dalley II, A. F. 2009. Grant's Atlas of Anatomy. $12^{\text {th }}$ ed. Lippincott Williams \& Wilkins, Philadelphia, 1- 664 .

Amson, E., de Muizon, C. 2014. A new durophagous phocid (Mammalia: Carnivora) from the late Neogene of Peru and considerations on monachine seals phylogeny. Journal of Systematic Palaeontology, 12 (5), 523-548.

Au, W. W., Hastings, M. C. 2008. Principles of marine bioacoustics. Springer, New York, 121-174.

Barklow, W. E. 2004. Amphibious communication with sound in hippos, Hippopotamus amphibius. Animal behaviour, 68 (5), 1125-1132.

Bastl, K., Nagel, D., Solé, F. 2017. Incus facet morphology in carnivorous mammals from different ecosystems: Taxonomy vs. habitat. Comptes Rendus Palevol, 16 (3), 284-302.

Berta, A., Adam, P. J. 2001. Evolutionary biology of pinnipeds. In: Mazin, J. M., de Buffrenil, V., eds. Secondary adaptation of tetrapods to a life in water. Verlag Dr Frederich Pfeil, München, 235-260.

Berta, A., Churchill, M. 2012. Pinniped taxonomy: review of currently recognized species and subspecies, and evidence used for their description. Mammal Review, 42 (3), 207-234.

Berta, A., Churchill, M., Boessenecker, R. W. 2018. The origin and evolutionary biology of pinnipeds: seals, sea lions, and walruses. Annual Review of Earth and Planetary Sciences, 46, 203-228.

Berta, A., Sumich, J., Kovacs, K. 2006. Marine mammals: evolutionary biology. Elsevier, 1-738. 
Bodson, A., Miersch, L., Dehnhardt, G. 2007. Underwater localization of pure tones by harbor seals (Phoca vitulina). The Journal of the Acoustical Society of America, 122 (4), 2263-2269.

Boessenecker, R. W., Churchill, M. 2015. The oldest known fur seal. Biology Letters, 11 (2), 20140835.

Buchanan, A. M. 1907. Manual of anatomy: systematic and practical, including embryology. Vol. 2. Baillière, Tindall and Cox, London, 577-1431.

Byl, J. A., Miersch, L., Wieskotten, S., Dehnhardt, G. 2016. Underwater sound localization of pure tones in the median plane by harbor seals (Phoca vitulina). The Journal of the Acoustical Society of America, 140 (6), 4490-4495.

Constantinescu, G. M. 2018. Illustrated Veterinary Anatomical Nomenclature. $4^{\text {th }}$ ed. Georg Thieme Verlag, Stuttgart.

Cozzuol, M. A. 2001. A "northern" seal from the Miocene of Argentina: implications for phocid phylogeny and biogeography. Journal of Vertebrate Paleontology, 21 (3), 415-421.

Cunningham, K. A., Reichmuth, C. 2016. High-frequency hearing in seals and sea lions. Hearing Research, 331, 83-91.

Cunningham, K. A., Hayes, S. A., Rub, A. M. W., Reichmuth, C. 2014. Auditory detection of ultrasonic coded transmitters by seals and sea lions. The Journal of the Acoustical Society of America, 135 (4), 1978-1985.

Cutnell, J. D., Johnson, K. W. 1998. Physics. Wiley, New York, 1-466.

Davis, H., Derbyshire, A. J., Lurie, M. H., Saul, L. J. 1934. The electric response of the cochlea. American Journal of Physiology-Legacy Content, 107 (2), 311-332.

Dechow, P. C., Wang, Q. 2017. Evolution of the Jugal/Zygomatic Bones. Anatomical Record, 300, 12-15.

Deméré, T. A., Berta, A., Adam, P. J. 2003. Chapter 3: Pinnipedimorph evolutionary biogeography. Bulletin of the American Museum of Natural History, 279, 32-76.

Dieterich, U. W. 1841. Von Strafen und Strafanstalten: Aus dem Schwedischen nach die zweiten Auflage. A. Bonnier.

Doran, A. H. 1878. XVIII. Morphology of the Mammalian Ossicula auditûs. Transactions of the Linnean Society of London. 2nd Series, Zoology, 1 (7), 371-497.

Ekdale, E. G. 2013. Comparative anatomy of the bony labyrinth (inner ear) of placental mammals. PLoS One, 8 (6), e66624.

Ekdale, E. G. 2015. Form and function of the mammalian inner ear. Journal of anatomy, 228 (2), 324-337.

Evans, H. E. 1993. Miller's Anatomy of the Dog. W. B. Saunders, Philadelphia, 1-872.

Evans, H. E., Christiansen, G. C. 1979. Miller's anatomy of the dog. W. B. Saunders.

Flower, W. H. 1869. On the value of the characters of the Order Carnivora, and on the systematic position of Bassaris and other disputed forms. Proceedings of Zoological Society of London, 4-37.

Ghoul, A., Reichmuth, C. 2014. Hearing in the sea otter (Enhydra lutris): Auditory profiles for an amphibious marine carnivore. Journal of Comparative Physiology A, 200 (11), 967-981.

Gray, A. A. 1913. Notes on the comparative anatomy of the middle ear. Journal of Anatomy and Physiology, 47 (4), 391.

Grohé, C., Tseng, Z. J., Lebrun, R., Boistel, R., Flynn, J. J. 2016. Bony labyrinth shape variation in extant Carnivora: a case study of Musteloidea. Journal of Anatomy, 228 (3), 366-383.

Hagenbach, E. 1835. Die Paukenhühle der Säugethiere: Ein Beitrag zur vergleichenden Anatomie des Gehörorgans. Leipzig.

Hanggi, E. B., Schusterman, R. J. 1994. Underwater acoustic displays and individual variation in male harbour seals, Phoca vitulina. Animal Behavior, 48, 1275-1283.

Heffner, R. S., Heffner, H. E. 1982. Hearing in the elephant (Elephas maximus): absolute sensitivity, frequency discrimination, and sound localization. Journal of comparative and physiological psychology, 96 (6), 926-944.

Heffner, H. E., Heffner, R. S. 2007. Hearing Ranges of Laboratory Animals. Journal of the American Association for Laboratory Animal Science, 46 (1), 20-22.

Heffner, R. S., Koay, G., Heffner, H. E. 2001. Audiograms of five species of rodents: implications for the evolution of hearing and the perception of pitch. Hearing Research, 157, 138-152.

Hemilä, S., Nummela, S., Reuter, T. 1995. What middle ear parameters tell about impedance matching and high frequency hearing. Hearing research, 85 (1-2), 31-44.

Hemilä, S., Nummela, S., Berta, A., Reuter, T. 2006. High-frequency hearing in phocid and otariid pinnipeds: An interpretation based on inertial and cochlear constraints. The Journal of the Acoustical Society of America, 120 (6), 3463-3466.

Henson, O. W. Jr. 1961. Some morphological and functional aspects of certain structures of the middle ear in bats and insectivores. University of Kansas Scientific Bulletin, 42 (3), 151-255.

Hermanson, J. W., Lahunta, A. D., Evans, H. E. 2020. Miller and Evan's Anatomy of the Dog. 5th Ed. Elsevier.

Holt, M. M., Schusterman, R. J., Southall, B. L., Kastak, D. 2004. Localization of aerial broadband noise by pinnipeds. The Journal of the Acoustical Society of America, 115 (5), 2339-2345.

Holt, M. M., Schusterman, R. J., Kastak, D., Southall, B. L. 2005. Localization of aerial pure tones by pinnipeds. The Journal of the Acoustical Society of America, 118 (6), 3921-3926. 
Holt, M. M., Schusterman, R. J. 2007. Spatial release from masking of aerial tones in pinnipeds. The Journal of the Acoustical Society of America, 121 (2), 1219-1225.

Hough, J. R. 1948. The auditory region in some members of the Procyonidae, Canidae and Ursidae: its significance in the phylogeny of the Carnivora. Bulletin of the American Museum of Natural History, 92, $67-118$.

Huang, G., Rosowski, J., Ravicz, M., Peake, W. 2002. Mammalian ear specializations in arid habitats: structural and functional evidence from sand cat (Felis margarita). Journal of Comparative Physiology A, 188 (9), 663-681.

Hunt, R. M. Jr. 1974. The auditory bulla in Carnivora: an anatomical basis for reappraisal of carnivore evolution. Journal of Morphology, 143 (1), 21-75.

Ivanoff, D. V. 2001. Partitions in the carnivoran auditory bulla: their formation and significance for systematics. Mammal Review, 31 (1), 1-16.

Ivanoff, D. V. 2007. Unlocking the ring: Occurrence and development of the uninterrupted intrabullar septum in Canidae. Mammalian Biology, 72 (3), 145-162.

Jones, J. M., Thayre, B. J., Roth, E. H., Mahoney, M., Sia, I., Merculief, K., Jackson, C., Zeller, C., Clare, M., Bacon, A., Weaver, S. 2014. Ringed, bearded, and ribbon seal vocalizations north of Barrow, Alaska: seasonal presence and relationship with sea ice. Arctic, 203-222.

Kardong, K. V. 2009. Vertebrates: Comparative Anatomy, Function, Evolution. McGraw-Hill Companies, New York, 687-705.

Kastak, D. A. 1997. Comparative aspects of hearing in pinnipeds. Doctoral Dissertation, University of California, Santa Cruz.

Kastak, D., Schusterman, R. J. 1998. Low-frequency amphibious hearing in pinnipeds: Methods, measurements, noise, and ecology. The Journal of the Acoustical Society of America, 103 (4), 2216-2228.

Kastak, D., Schusterman, R. J. 1999. In-air and underwater hearing sensitivity of a northern elephant seal (Mirounga angustirostris). Canadian Journal of Zoology, 77, 1751-1758.

Kastelein, R. A., Dubbeldam, J. L., De Bakker, M. A. G., Gerrits, N. M. 1996 a. The anatomy of the walrus head (Odobenus rosmarus). Part 4: The ears and their function in aerial and underwater hearing. Aquatic Mammals, 22, 95-126.

Kastelein, R. A., Mosterd, P., Van Ligtenberg, C. L., Verboom, W. C. 1996 b. Aerial heating sensitivity tests with a male Pacific walrus (Odobenus rosmarus divergens) in the free field and with headphones. Aquatic Mammals, 22, 81-94.

Kastelein, R. A., Mosterd, P., Van Santen, B., Hagedoorn, M., de Haan, D. 2002. Underwater audiogram of a Pacific walrus (Odobenus rosmarus divergens) measured with narrow-band frequency-modulated signals. The Journal of the Acoustical Society of America, 112 (5), 2173-2182.

Kastelein, R. A., van Schie, R., Verboom, W. C., de Haan, D. 2005. Underwater hearing sensitivity of a male and a female Steller sea lion (Eumetopias jubatus). The Journal of the Acoustical Society of America, 118 (3), 1820-1829.

Kastelein, R. A., Wensveen, P. J., Hoek, L., Verboom, W. C., Terhune, J. M. 2009. Underwater detection of tonal signals between 0.125 and $100 \mathrm{kHz}$ by harbor seals (Phoca vitulina). The Journal of the Acoustical Society of America, 125 (2), 1222-1229.

Ketten, D. R. 1992. The marine mammal ear: specializations for aquatic audition and echolocation. In: Webster, D. B., Fay, R. R., Popper, A. N., eds. The evolutionary biology of hearing. Springer, New York, 717-750.

Koretsky, I. A., Holec, P. 2002. A primitive seal (Mammalia: Phocidae) from the early middle Miocene of Central Paratethys. Smithsonian Contributions to Paleobiology, 93, 163-178.

Koretsky, I. A., Rahmat, S. J. 2015. A new species of the subfamily Devinophocinae (Carnivora, Phocidae) from the Central Paratethys. Rivista Italiana di Paleontologia e Stratigrafia, 121 (1), 31-47.

Koretsky, I. A., Barnes, L. G., Rahmat, S. J. 2016. Re-evaluation of morphological characters questions current views of pinniped origins. Vestnik Zoologii, 50 (4), 327-354.

Langman, J., Woerdeman, M. W. 1978. Atlas of Medical Anatomy. W. B. Saunders Company, Philadelphia, 1-407.

Loza, C. M., Latimer, A. E., Sánchez-Villagra, M. R., Carlini, A. A. 2017. Sensory anatomy of the most aquatic of carnivorans: the Antarctic Ross seal, and convergences with other mammals. Biology letters, 13 (10), 20170489.

Loza, C. M., Reutimann, O., Sánchez-Villagra, M. R., Carlini, A. A., Aguirre-Fernández, G. 2018 a. Evolutionary transformations of the malleus in pinnipeds, with emphasis on Southern Hemisphere taxa. Contributions to Zoology, 87 (2), 75-85.

Loza, C. M., Scarano, A. C., Galliari, F. C., Soibelzon, L. H., Negrete, J., Carlini, A. A. 2018 b. The tympanic region of Otaria byronia (Otariidae, Carnivora) - morphology, ontogeny, age classes and dimorphism. Journal of anatomy, 232 (1), 54-71.

Loza, C. M., Scarano, A. C., Soibelzon, L. H., Negrete, J., Carlini, A. A. 2015. Morphology of the tympanic-basicranial region in Mirounga leonina (Phocidae, Carnivora), postnatal ontogeny and sexual dimorphism. Journal of anatomy, 226 (4), 354-372. 
Lucke, K., Hastie, G. D., Ternes, K., McConnell, B., Moss, S., Russell, D. J., Weber, H., Janik, V. M. 2016. Aerial low-frequency hearing in captive and free-ranging harbour seals (Phoca vitulina) measured using auditory brainstem responses. Journal of Comparative Physiology A, 202 (12), 859-868.

MacPhee, R. D. E. 1981. Auditory regions of primates and eutherian insectivores: morphology, ontogeny and character analysis. Contributions to Primatology, 18, 1-282.

Marsh, S. E. 2001. Morphometric analysis of ears in two families of pinnipeds. PhD thesis, Massachusetts Institute of Technology and Woods Hole Oceanographic Institution.

Mason, M. J. 2016. Structure and function of the mammalian middle ear. II: Inferring function from structure. Journal of Anatomy, 228, 300-312.

Mennink, L. M., van Dijk, J. M. C., van Dijk, P. 2020. The cerebellar (para)flocculus: A review on its auditory function and a possible role in tinnitus. Hearing Research, 398, 108081.

Mivart, G. 1881. The cat. Charles Scribner's Sons, New York, 1-557.

Møhl, B., Ronald, K. 1975. The peripheral auditory system of the harp seal, Pagophilus groenlandicus (Erxleben, 1777). Rapp. P.-v. Réun. Cons. Int. Explor. Mer, 169, 516-523.

Morton, P. G. 1989. Health Assessment in Nursing. Springhouse Corporation, Pennsylvania, 1-232.

Mossbridge, J. A., Thomas, J. A. 1999. An "acoustic niche" for Antarctic killer whale and leopard seal sounds. Marine Mammal Science, 15 (4), 1351-1357.

Nakajima, H. H., Ravicz, M. E., Merchant, S. N., Peake, W. T., Rosowski, J. J. 2005. Experimental ossicular fixations and the middle ear's response to sound: evidence for a flexible ossicular chain. Hearing research, 204 (1-2), 60-77.

Nomina Anatomica Veterinaria. 5th edition. 2005. Available: www.wava-amav.org/Downloads/nav_2005.pdf. Accessed 2019 Dec 8.

Nomina Anatomica Veterinaria. 6th edition. 2017. Available: www.wava amav.org/Downloads/nav_2017.pdf. Accessed 2020 May 23.

Novacek, M. J. 1977. Aspects of the problem of variation, origin and evolution of the eutherian auditory bulla. Mammal Review, 7 (3-4), 131-150.

Nowak, R. M. 1991. Walker's Mammals of the World. (Vol. 2). John Hopkins University Press, Maryland, $1-1629$.

Nummela, S. 1995. Scaling of the mammalian middle ear. Hearing research, 85 (1-2), 18-30.

Nummela, S. 2008. Hearing in aquatic mammals. In: Thewissen, J. G. M., Nummela, S., eds. Sensory evolution on the threshold: adaptations in secondarily aquatic vertebrates. University of California Press, Berkeley, 211-231.

Nummela, S., Thewissen, J. G. M., Bajpai, S., Hussain, T., Kumar, K. 2007. Sound transmission in archaic and modern whales: anatomical adaptations for underwater hearing. The Anatomical Record, 290 (6), 716-733.

Paul, M. C. 2014. Die Anatomie des Mittel-und Innenohres bei “Meles meles, Martes martes" und "Lutra lutra"mittels computertomographischen Analysen. Doctoral dissertation, Universität wien.

Pocock, R. I. 1916. The tympanic bulla in hyaenas. Proceedings of the Zoological Society of London, 303-307.

Polly, P. D., Wesley-Hunt, G. D., Heinrich, R. E., Davis, G., Houde, P. 2006. Earliest known carnivoran auditory bulla and support for a recent origin of crown-group Carnivora (Eutheria, Mammalia). Palaeontology, 49 (5), 1019-1027.

Puria, S., Steele, C. 2010. Tympanic-membrane and malleus-incus-complex co-adaptations for high-frequency hearing in mammals. Hearing research, 263 (1-2), 183-190.

Purves, D. E., Augustine, G. J., Fitzpatrick, D. E., Hall, W. C., LaMantia, A. S. E, McNamara, J. O., White, L. E. 2008. Neuroscience. Sinaur Associates, Sunderland, MA.

Reichmuth, C., Holt, M. M., Mulsow, J., Sills, J. M., Southall, B. L. 2013. Comparative assessment of amphibious hearing in pinnipeds. Journal of Comparative Physiology A, 199 (6), 491-507.

Repenning, C. A. 1972. Underwater hearing in seals: Functional morphology. In: Harrison, R. J., ed. Functional Anatomy of Marine Mammals. Academic Press, New York, 1, 307-331.

Repenning, C. A. 1976. Adaptive evolution of sea lions and walruses. Systematic Zoology, 25 (4), 375-390.

Riedman, M. 1990. The pinnipeds: seals, sea lions, and walruses. University of California Press, 12, 38-63.

Romer, A. S., Parsons, T. S. 1986. The Vertebrate Body. Philadelphia, Sanders, 237-272.

Segall, W. 1943. The auditory region of the arctoid carnivores. Zoological Series, Field Museum of Natural History, 29, 33-59.

Sills, J. M., Southall, B. L., Reichmuth, C. 2014. Amphibious hearing in spotted seals (Phoca largha): underwater audiograms, aerial audiograms and critical ratio measurements. Journal of Experimental Biology, 217 (5), 726-734.

Sills, J. M., Southall, B. L., Reichmuth, C. 2015. Amphibious hearing in ringed seals (Pusa hispida): underwater audiograms, aerial audiograms and critical ratio measurements. Journal of Experimental Biology, 218 (14), 2250-2259.

Smodlaka, H., Khamas, W. A., Jungers, H., Pan, R., Al-Tikriti, M., Borovac, J. A., Palmer, L., Bukac, M. 2018. A Novel Understanding of Phocidae Hearing Adaptations Through a Study of Northern Elephant Seal (Mirounga angustirostris) Ear Anatomy and Histology. The Anatomical Record, 302 (9), 1605-1614.

Straus-Durchkheim, H. 1845. Anatomie Descriptive et Comparative du Chat. Paris, 409-414. 
Tedford, R. H. 1976. Relationship of pinnipeds to other carnivores (Mammalia). Systematic Zoology, 25 (4), 363-374.

Thomassin, J. M., Dessi, P., Danvin, J. B., Forman, C. 2008. Anatomía del oído medio. EMC Otorrinolaringología, 37 (3), 1-20.

Van der Klaauw, C. J. 1922. Über die Entwickelung des Entotympanicums. Leiden, 1-50.

Van Kampen, P. N. 1905. Die Tympanalgegend des Säugetierschädels. Morphol Jahrb, 34, 237-265.

Wang, X., Tedford, R. H., Antón, M. 2008. The dog family, Canidae, and their evolutionary history. Columbia University Press, New York.

Wible, J. R. 1991. Origin of Mammalia: the craniodental evidence reexamined. Journal of Vertebrate Paleontology, 11 (1), 1-28.

Wible, J. R. 2008. On the cranial osteology of the Hispaniolan solenodon, Solenodon paradoxus Brandt, 1833 (Mammalia, Lipotyphla, Solenodontidae). Annals of Carnegie Museum, 77 (3), 321-402.

Wible, J. R. 2010. Petrosal anatomy of the nine-banded armadillo, Dasypus novemcinctus Linnaeus, 1758 (Mammalia, Xenarthra, Dasypodidae). Annals of Carnegie Museum, 79 (1), 1-28.

Wible, J. R. 2011. On the treeshrew skull (Mammalia, Placentalia, Scandentia). Annals of Carnegie Museum, 79 (3), 149-230.

Wible, J. R., Spaulding, M. 2012. A reexamination of the Carnivora malleus (Mammalia, Placentalia). PLoS One, 7 (11), e50485.

Wińcza, H. 1896. Über einige Entwickelungsveränderungen in der Gegend des Schädelgrundes bei den Säugethieren. Bull Int Acad Sci Crac 1896, 326-337.

Wolsan, M. 1993. Phylogeny and classification of early European Mustelida (Mammalia: Carnivora). Acta Theriologica, 38 (4), 345-384.

Wyss, A. R. 1987. The walrus auditory region and the monophyly of pinnipeds. American Museum novitates, 2871, 1-31.

Yazdi, F. T., Colangelo, P., Adriaens, D. 2015. Testing a long-standing hypothesis on the relation between the auditory bulla size and environmental conditions: a case study in two jird species (Muridae: Meriones libycus and M. crassus). Mammalia, 79 (2), 185-200.

Received 29 October 2020

Accepted 5 January 2021 